OPEN ACCESS

Edited by:

Chao Wang,

Soochow University, China

Reviewed by:

Jianxun J. Song,

Texas A\&M Health Science Center.

United States

Hongling $W u$,

Guangzhou Institutes of Biomedicine and Health (CAS), China

${ }^{*}$ Correspondence: Methichit Wattanapanitch methichit.wat@mahidol.ac.th

Specialty section: This article was submitted to

Cancer Immunity and Immunotherapy,

a section of the journal

Frontiers in Immunology

Received: 16 August 2021 Accepted: 13 September 2021 Published: 28 September 2021

Citation:

Netsrithong $R$ and Wattanapanitch $M$ (2021) Advances in Adoptive Cell

Therapy Using Induced Pluripotent Stem Cell-Derived T Cells.

Front. Immunol. 12:759558. doi: 10.3389/fimmu.2021.759558

\section{Advances in Adoptive Cell Therapy Using Induced Pluripotent Stem Cell-Derived T Cells}

\author{
Ratchapong Netsrithong ${ }^{1,2}$ and Methichit Wattanapanitch ${ }^{1 *}$ \\ 1 Siriraj Center for Regenerative Medicine, Faculty of Medicine Siriraj Hospital, Mahidol University, Bangkok, Thailand, \\ ${ }^{2}$ Department of Immunology, Faculty of Medicine Siriraj Hospital, Mahidol University, Bangkok, Thailand
}

Adoptive cell therapy (ACT) using chimeric antigen receptor (CAR) T cells holds impressive clinical outcomes especially in patients who are refractory to other kinds of therapy. However, many challenges hinder its clinical applications. For example, patients who undergo chemotherapy usually have an insufficient number of autologous $T$ cells due to lymphopenia. Long-term ex vivo expansion can result in T cell exhaustion, which reduces the effector function. There is also a batch-to-batch variation during the manufacturing process, making it difficult to standardize and validate the cell products. In addition, the process is labor-intensive and costly. Generation of universal off-the-shelf CAR T cells, which can be broadly given to any patient, prepared in advance and ready to use, would be ideal and more cost-effective. Human induced pluripotent stem cells (iPSCs) provide a renewable source of cells that can be genetically engineered and differentiated into immune cells with enhanced anti-tumor cytotoxicity. This review describes basic knowledge of T cell biology, applications in ACT, the use of iPSCs as a new source of $T$ cells and current differentiation strategies used to generate $T$ cells as well as recent advances in genome engineering to produce next-generation off-the-shelf $T$ cells with improved effector functions. We also discuss challenges in the field and future perspectives toward the final universal off-the-shelf immunotherapeutic products.

Keywords: adoptive cell therapy, induced pluripotent stem cells, T cells, chimeric antigen receptor, tumor infiltrating lymphocytes, cancer immunotherapy, off-the-shelf $T$ cells

\section{INTRODUCTION}

Adoptive cell therapy (ACT) of T lymphocytes offers a potential therapy for chronic viral infection and cancers. ACT can be achieved by isolating $\mathrm{T}$ cells from the excised tumor mass (tumor infiltrating lymphocytes or TILs), ex vivo expanding and reinfusing them into the patient to target viral or tumor antigens $(1,2)$. However, the process of TIL isolation and expansion limits their clinical applications since it is technically difficult, labor-intensive, costly and difficult to standardize. TILs do not often provide potent anti-tumor effects due to exhaustion of $\mathrm{T}$ cells. In addition, identification of antigen-specific $\mathrm{T}$ cells in other solid tumors is very challenging (3). To improve specificity and cytotoxicity of ACT, genetic engineering approaches to target the antigens by transduction of antigen-specific T cell receptor (TCR) or chimeric antigen receptor (CAR) gene can be performed. The engineered $\mathrm{T}$ cells are then expanded and reinfused into the patient after 
lymphodepletion. The TCR-engineered T cells recognize target antigens, which are processed within the cytoplasm and presented by specific human leukocyte antigen (HLA) or major histocompatibility complex (MHC) class I molecules on the surface of the viral-infected cells or cancer cells (4). Several studies reported the use of TCR-engineered $\mathrm{T}$ cells to treat patients including NY-ESO-1-directed tTCR and MAGE-A3directed tTCR for multiple myeloma $(\operatorname{MM})(5,6)$, and WT1directed tTCR for acute myeloid leukemia (AML) (7). However, ACT using TCR-engineered T cells is limited by the need to engineer TCR specific for antigen and MHC molecules of the patient.

In contrast, antigen recognition by CAR is mediated by a synthetic hybrid receptor composed of an extracellular antigenrecognition domain, which is a single-chain variable fragment $(\mathrm{scFv})$ derived from the variable regions of a monoclonal antibody (mAb), a transmembrane (TM) domain and intracellular signaling domains such as TCR-derived $\mathrm{CD} 3 \zeta$ and co-stimulatory domains (CD28 or 4-1BB) (8). Unlike TCRengineered $\mathrm{T}$ cells, CAR $\mathrm{T}$ cells can recognize a specific antigen and eliminate the tumor cells in an HLA-independent manner, therefore, enhancing therapeutic outcomes. Clinical trials using CAR T cell therapy showed a long-term remission in both hematological malignancies and solid tumors $(9,10)$. To date, the US FDA approved four CD19-directed CAR T cell products: Kymriah ${ }^{\mathrm{TM}}$ in 2017 and Yescarta ${ }^{\mathrm{TM}}$ in 2018, Tecartus ${ }^{\mathrm{TM}}$ in 2020, and recently Breyanzi ${ }^{\circledR}$ in 2021, for the treatment of relapsed or refractory $B$ cell malignancies $(1,2)$. Despite its remarkable success, ACT using autologous TCR- or CARengineered $\mathrm{T}$ cells has some unavoidable limitations. The ACT therapy relies on personalized manufacture, which proves very challenging in terms of time and cost to manufacture $\mathrm{T}$ cells thereby restrictive for large-scale clinical applications. Moreover, it is also technically difficult to obtain sufficient number of autologous $\mathrm{T}$ cells from lymphopenic patients who are heavily pretreated with chemotherapy, or immunodeficient patients, to generate a clinically relevant dose of T cells for therapy $(3,11)$. In order to obtain sufficient number of cytotoxic T cells (CTLs) for ACT, ex vivo expansion to enrich the number of CTLs is required before infusion. This process involves several stimulation steps using various cytokines to increase $\mathrm{T}$ cell proliferation. Longterm culture can drive CTLs into an "exhausted state", where CTLs have shortened telomere length, and lose proliferative capacity and effector function, which hinder their clinical practicality $(4,5)$.

One way to generate an unlimited supply of universal allogeneic CAR T cells for cancer immunotherapy is to use induced pluripotent stem cells (iPSCs) as a starting material. Advances in iPSC technology have made the generation of autologous pluripotent stem cells (PSCs) possible. These cells have unlimited proliferation and can be differentiated into all specialized cell types of the body; therefore, they represent an autologous renewable cell source for regenerative medicine. iPSCs can be derived from various somatic cell sources, mainly skin fibroblasts and peripheral blood, by introducing the Yamanaka factors (OCT4, SOX2, KLF4 and c-MYC) $(6,7)$.
One of the useful applications of iPSCs in regenerative medicine is the production of CTLs for viral or cancer immunotherapy. Previous studies demonstrated that iPSCs generated from $\mathrm{T}$ cells retained rearranged TCR genes. Upon differentiation toward $\mathrm{T}$ cell lineage, the iPSC-derived $\mathrm{T}$ cells re-expressed the same TCR as those of the parental T cells $(8,9)$. In addition, iPSCs are amenable to genetic modification, so it is possible to engineer the cells to have enhanced specificity and effector functions. Since iPSCs can be expanded unlimitedly, clinical-scale quantities of $\mathrm{T}$ cells with the desired antigen specificity can be manufactured. In this review, we provide the basic knowledge and recent advances of iPSC-derived $\mathrm{T}$ cell generation for clinical applications starting from the initial cell source for iPSC generation to the applications of iPSC-derived $\mathrm{T}$ cell products for cell-based therapy. In addition, we summarize future directions and challenges towards the final universal, off-the-shelf immunotherapeutic products.

\section{T CELL BIOLOGY AND APPLICATIONS IN ACT}

$\mathrm{T}$ cells play an essential role in the host defense mechanism against pathogens and cancers. They can be distinguished from other types of lymphocytes by the expression of TCR, which binds to the foreign antigen presented on the MHC. This interaction induces the release of cytotoxic granules and expression of Fas-ligand, which results in the target cell apoptosis (10). T cells originate from hematopoietic stem cells (HSCs), which give rise to all blood cell lineages. HSCs in the bone marrow differentiate into common myeloid progenitors (CMPs), which produce granulocyte-macrophage progenitors (GMPs) and megakaryocyte-erythroid progenitors (MEPs), or common lymphoid progenitors (CLPs), which produce lymphoid cells (12). T cell development occurs after CLPs from the bone marrow migrate into the thymus via the bloodstream. In the thymus, CLPs receive the Notch signal from cortical thymic epithelial cells (cTECs). During the first step of T cell development, the Notch signal stimulates CLPs to commit to double-negative (DN) cells (CD8 $\left.{ }^{-} / \mathrm{CD}^{-}\right)$(13), which can be divided into four subpopulations (DN1 to DN4) based on the expression of CD25 and CD44 (14). From the DN1 to DN4 stages, the precursor cells undergo TCR rearrangement mediated by RAG protein to generate TCR. TCRs are randomly generated and are unique for each precursor cell. After successful TCR rearrangement, the DN4 cells express both co-receptors, CD4 and CD8 (double-positive (DP) cells). During this step, the DP cells undergo a positive selection in the cortex; the DP cells expressing TCRs that are able to bind to MHC molecules plus self-antigens on the cTEC surface with appropriate affinity will be retained (15). The outcomes of the positive selection depend on the signals from TCRs and the co-receptors (CD4 or CD8). If the DP cells have TCRs that are able to bind to MHC class II of cTECs, the DP cells will become CD4 single-positive (SP) cells by downregulating CD8 expression. On the other hand, if the DP cells have TCRs that fit the MHC class I molecule, the DP cells 
will downregulate the expression of CD4 and become CD8 SP cells. The DP cells that receive too low TCR signals or no TCR signals for self-antigen-MHC molecules will undergo apoptosis to prevent the generation of useless $\mathrm{T}$ cells (16).

Apart from positive selection, TECs also involve in negative selection, the process to eradicate the autoreactive T cells. In this process, the SP cells migrate to the medullar of the thymus where the SP cells encounter more diverse self-antigen MHC provided by medullary thymic epithelial cells (mTECs) and dendritic cells. The SP cells that bind with high affinity to the self-antigen will be eliminated from TCR repertoires by apoptosis (17). The process of negative selection generates mature $\mathrm{T}$ cells with a highly diverse TCR repertoire and self-tolerance to enter the bloodstream and circulate to peripheral tissues in response to pathogens (18). The newly generated T cells are considered naïve $\mathrm{T}$ cells at this stage because they have not been exposed to an antigen. When the naïve $\mathrm{T}$ cells interact with an antigenpresenting cell showing the $\mathrm{MHC} /$ peptide complex that can specifically bind to their TCR, T cell activation is initiated. This activation triggers the proliferation of the naïve $\mathrm{T}$ cell clone and differentiates the naive $\mathrm{T}$ cells into the effector $\mathrm{T}$ cells. During this period, $\mathrm{CD}^{+}$and $\mathrm{CD}^{+} \mathrm{T}$ cells exhibit inflammatory cytokine secretion and cytotoxicity toward the transformed cells or infected cells, respectively. If the pathogen is successfully eliminated, the majority of effector $\mathrm{T}$ cells will die while the surviving effector $\mathrm{T}$ cells will be differentiated further to the memory cells. These cells are inactive and maintained for long-term immunity (19).

In 1987, Rosenberg and colleagues reported the first ACT using TILs to treat patients with metastatic malignant melanoma. TILs were expanded by in vitro culture in the presence of recombinant interleukin 2 (IL-2) and transfused into the patients to treat melanoma. The results demonstrated that TILs had autologous tumor-specific cytotoxicity; in addition, TILs from some patients also had limited capacity to kill allogeneic fresh tumor targets suggesting that adoptive transfer of TILs could be a potential approach for the treatment of cancer patients (20). In 1994, a larger number of patients with metastatic melanoma were treated with autologous TILs with IL-2, with or without the administration of cyclophosphamide. However, the results demonstrated that only 5 of 29 patients had complete responses (21). It was subsequently shown that lymphodepletion prior to ACT increased the complete response rate of the therapy $(22,23)$, and this finding led to a breakthrough in ACT against melanoma. However, TIL treatments in some types of solid cancer, such as breast cancer or cholangiocarcinoma, are not as effective as in melanomas (24), and the number of TILs is often insufficient for the treatment. To enhance the specificity of $\mathrm{T}$ cells and efficacy of ACT, TILs from the patients were transduced with transgenic TCR (25). These engineered TILs simultaneously react with two different antigens. Previous studies showed that the infusion of NY-ESO1 TCR-engineered T cells resulted in tumor regression in melanoma and synovial sarcoma patients $(26,27)$. Although genetic-engineered $\mathrm{T}$ cells have been developed against many antigens, their TCRs must bind to the tumor antigen presented on the HLA class I molecule to mediate the specific killing effect. This process often results in poor treatment efficacy since tumors can downregulate HLA class I molecules and co-stimulatory molecules $(28,29)$. To overcome this problem, CAR technology has been developed. The first generation of CAR invented in $1989(30,31)$ comprises the $\mathrm{scFv}$ from the antibody fused with the transmembrane domain of TCR, which contains the transduction signal, $\mathrm{CD} 3 \zeta$ chain. In the second and third generations of CAR, the co-stimulatory domains derived from CD28, 4-1BB, or OX40 are added to enhance $\mathrm{T}$ cell activation and improve CAR $\mathrm{T}$ cell function against the tumors that do not express co-stimulatory molecules (32).

Although the clinical outcomes of CAR T cell therapy have been very impressive, the manufacturing costs for a single infusion of these novel therapies are very costly: $\$ 475,000$ for Kymriah and $\$ 373,000$ for Yescarta, making them inaccessible to most patients $(33,34)$. These prices do not include the hospitalization fees; therefore, the cost for the treatment needs to be reduced in order to make it economically practical and accessible to most cancer patients. Another important limitation of ACT is to find a healthy HLA-matched donor; therefore, some transplant centers focus on developing third-party $\mathrm{T}$ cell banks from common HLA donors (35). Other efforts have been made to generate universal allogeneic CAR $\mathrm{T}$ cells, which utilize healthy donor $\mathrm{T}$ cells for CAR and TCR engineering to increase antigen specificity and avoid graft-versus-host disease (GvHD), respectively (36-41). The treatment using these universal allogeneic CD19 CAR T cells (UCART19) demonstrated great success in two pediatric patients with acute lymphoblastic leukemia (ALL) (40). Recently, the successful results from two multicenter phase 1 studies using UCART19 in patients with relapsed and/or refractory B-ALL emphasize the potential of CAR T cells to induce complete remission in $67 \%$ of patients, even in the patients with high disease burden (42). However, there are some concerns regarding the manufacturing process; prolonged ex vivo culture can cause $\mathrm{T}$ cell exhaustion and reduced effector functions. In addition, there is also batchto-batch variability during the manufacturing process. Therefore, clinical studies with larger cohorts are required to validate allogeneic CAR T cells (43).

\section{INDUCED PLURIPOTENT STEM CELLS AS A NEW CELL SOURCE FOR ACT}

Although ACT of functional CTLs has offered a potential therapy for viral infection and cancers, the ex vivo expansion of autologous $\mathrm{T}$ cells has proved very challenging. This problem can be overcome by regenerating antigen-specific CTLs through iPSC reprogramming. Previous studies demonstrated that iPSCderived CTLs could be expanded from 100-fold to 1,000-fold within two weeks of culture compared to 20 -fold of the original $\mathrm{T}$ cells. These regenerated CTLs also exhibited higher telomerase activity and longer telomere length than the original $\mathrm{T}$ cells. 
Furthermore, the marker of exhausted T cells, PD-1, was not expressed, whereas the markers of central memory T cells, CCR7, CD27 and CD28, were co-expressed (9). In a more recent study, the regenerated CD8 $\alpha \beta$ CTLs were expanded up to 10,000 -fold and changed their phenotype from a naïve to an effector/memory profile. In this study, $10^{4}$ iPSCs were used to generate $10^{9}-10^{10}$ CD8 $\alpha \beta$ CTLs sufficient for a single transfusion (44). Apart from the regeneration of CTLs, iPSCs also provide an unlimited cell source for other $\mathrm{T}$ cells subsets such as regulatory $\mathrm{T}$ cells (Tregs) (45). Tregs play a critical role in suppressing cell-mediated immunity leading to the maintenance of immunological tolerance. Patients with autoimmune disorders have been found to have lower levels of Tregs (46). Furthermore, patients with type 1 diabetes (T1D) also have a deficient number of Tregs (47). Therefore, the generation of a large number of functional Tregs followed by ACT to autoimmune patients is required to suppress the hyperactivity of autoreactive T cells. Due to a low frequency of Treg in peripheral blood ( $1-2 \%$ in humans), several attempts have been made to generate Tregs from iPSCs for use in ACT. The first proof-of-concept study showed that mouse iPSC-derived Tregs could control the development of collagen-induced arthritis in the rheumatoid arthritis mouse model (48). Similarly, the mouse iPSC-derived Tregs could migrate to the pancreas and prevent the destruction of pancreatic $\beta$-cells by autoreactive $\mathrm{T}$ cells in the T1D mouse model (49). Therefore, a combination of iPSC technology with adoptive immunotherapy or CAR technology may provide a large number of $\mathrm{T}$ cells for future clinical applications.

Unlike other differentiated cell types, the generation of functional CTLs with a specific TCR from iPSCs depends significantly on the original somatic cell sources (Figure 1). When using non-T cell sources such as fibroblasts or keratinocytes as a somatic cell source, the derived iPSC clones bear the germline TCR gene. After T cell differentiation in vitro, the iPSC-derived $\mathrm{T}$ lymphocytes are generated with unpredictably rearranged TCR. This process recapitulates normal $\mathrm{T}$ cell development where sequential expression of CD7, cytoplasmic CD3, and surface CD3 was observed followed by TCR gene rearrangement of the $\gamma \delta$ and $\alpha \beta$ loci, respectively (50). However, without autologous TECs, positive and negative selection may not occur. Therefore, these iPSCs can only be used for studying normal $\mathrm{T}$ cell development and disease modeling; they are not suitable for clinical use due to the concern about autoreactive $\mathrm{T}$ cells. Apart from studying normal T cell development, diseasespecific iPSCs can be generated from somatic cells (non-T cells) of patients with inherited diseases affecting the immune system such as X-linked Severe Combined Immunodeficiency (SCID-X1) with the Interleukin-2 receptor gamma chain $(I L-2 R \gamma)$ mutation (51) or recombination-activating gene 1 (RAG1) mutations (52) to study abnormal $\mathrm{T}$ cell development in these disease models. Genetic correction in these disease-specific iPSCs using genome editing technologies such as TALENs or CRISPR/Cas9 systems with a subsequent in vitro differentiation also offers great potentials for future autologous therapy (51).

In 2011, Seki et al. developed the method for iPSC generation from mature human peripheral blood T cells using a Sendai viral vector to avoid transgene insertion (53). This method could generate iPSCs from a small amount (approximately $1 \mathrm{ml}$ ) of human peripheral blood samples (54). However, their method used fetal bovine serum (FBS) and mouse embryonic fibroblasts (MEF) as feeder cells, which result in contamination of xenogeneic antigens and zoonotic pathogens. In 2014, the generation of human iPSCs from peripheral blood $\mathrm{T}$ cells in a defined culture system was achieved using Sendai viral transduction and various combinations of chemically defined culture medium and coating matrices. For example, the combination of mTeSR1 medium and Matrigel resulted in the highest reprogramming efficiency $(0.005 \%)$ (55). Overall, the reprogramming efficiencies under the feeder-free system are generally lower than those using the feeder cells. Even though the reprogramming efficiency using blood cells is lower than fibroblasts, blood cells are preferable because the isolation is minimally-invasive and easy to perform.

On the other hand, generation of iPSCs from T cells results in the pre-rearranged TCR gene in the iPSC clones. The rearranged TCR can eliminate the risk of autoreactive TCR since the T cells undergo positive and negative selection in the thymus. However, the specificity of TCR is unknown. In 2013, Themeli et al. reported the generation of CD19 CAR-engineered T-iPSCs that can efficiently be differentiated into CAR T cells against CD $19^{+}$ malignant $\mathrm{B}$ cells in vitro. These T-iPSC-derived CAR $\mathrm{T}$ cells displayed therapeutic activity by potently inhibiting tumor growth in a mouse model (56). Similarly, Minagawa et al. demonstrated that when the monocyte-derived iPSCs were transduced with a transgenic antigen-specific TCR, these cells exhibited a monoclonal expression of the transduced TCR after $\mathrm{T}$ cell differentiation in vitro. The iPSC-derived transgenic TCR T cells could also delay tumor progression in xenograft cancer models (57). These two studies showed that even though the iPSCs have no antigen-specific TCR, the specificity of iPSC-derived $\mathrm{T}$ cells can be achieved by transduction of CAR or transgenic TCR to generate therapeutic T cells for cancer immunotherapy.

After the concept of $\mathrm{T}$ cell production utilizing PSCs has been proposed, Watarai et al. utilized the nuclear transfer technique to reprogram NKT cells. The nuclear transfer ESCs bearing rearranged invariant $\mathrm{V} \alpha 14-\mathrm{J} \alpha 18 \mathrm{TCR} \alpha$ gene were established from the mouse NKT cells (58). This study has proved that the rearranged TCR gene was retained throughout the reprogramming and differentiation process. Advances in the iPSC technology in 2006 led to reprogramming of $\mathrm{CD}^{+} \mathrm{T}$ cells specific to $\mathrm{MART}^{+}$melanoma using Sendai viral vectors carrying OSKM factors and SV40 large T antigen at MOI 30. Analysis of TCR $\alpha$ chain mRNA in the $\mathrm{CD}^{+} \mathrm{T}$ cells generated from these iPSCs confirmed that the iPSC-derived $\mathrm{CD}^{+} \mathrm{T}$ cells expressed the same TCR $\alpha$ chain gene as the parental MART1-specific T cells (8). Similarly, Nishimura et al. reported successful reprogramming of antigen-specific T cells into iPSCs. First, the transduction was performed using six retroviral vectors encoding OCT3/4, SOX2, KLF4, c-MYC, NANOG, and LIN28A; however, no iPSC-like colonies were observed. In the second attempt, the reprogramming was performed using the Sendai viral $(\mathrm{SeV})$ vector system consisting of two Sendai viral vectors. The first 


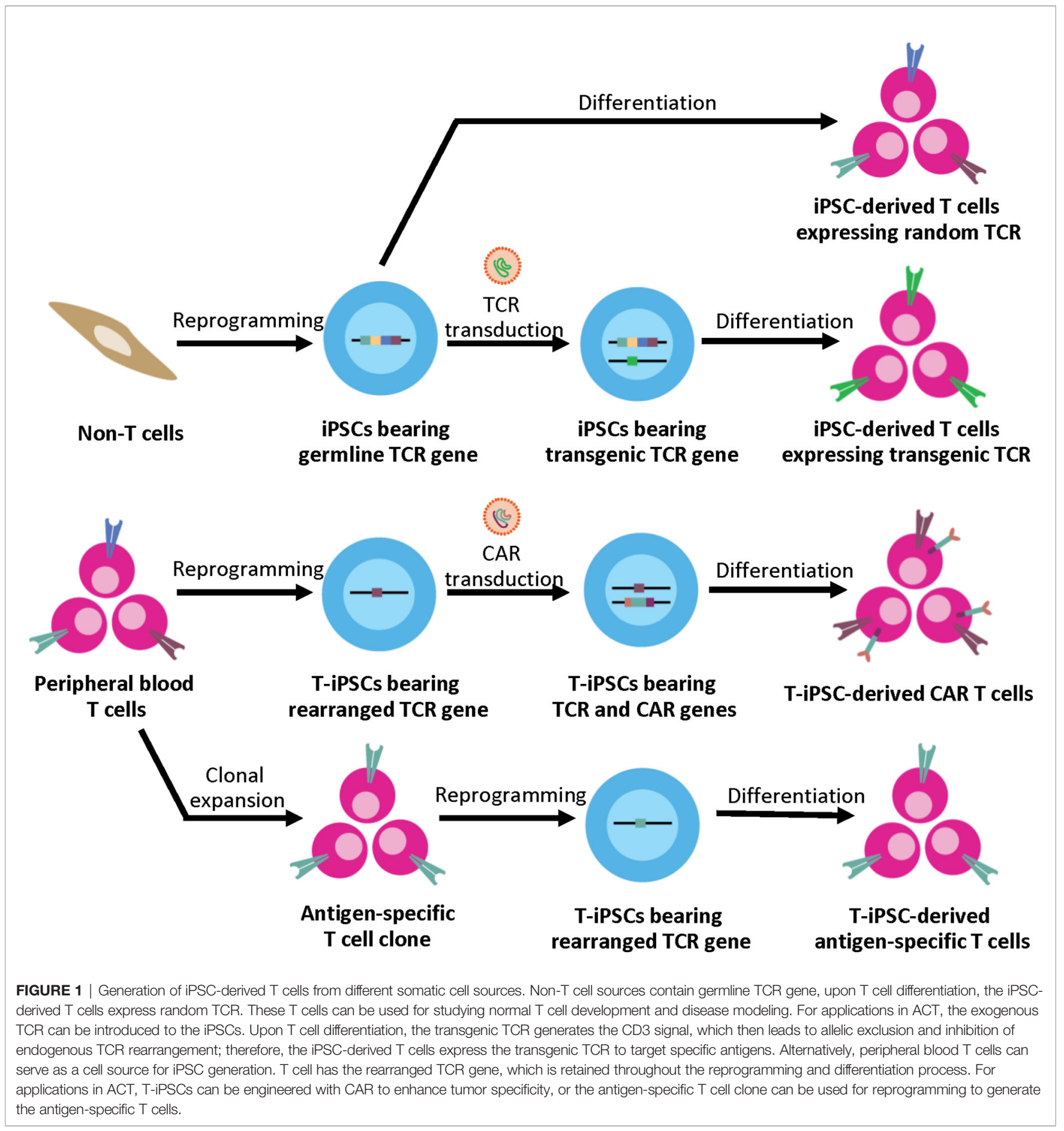

vector encodes OSKM factors and the microRNA-302, while the second vector encodes the SV40 large T (LT) antigen. The iPSClike colonies appeared on the mouse embryonic fibroblast (MEF) feeder cells within 40 days after transduction (9). The same approach enables reprogramming of several $\mathrm{T}$ cell clones specific for Nef antigen in HIV, pp65 antigen in cytomegalovirus (CMV), glutamic acid decarboxylase (GAD) antigen in type 1 diabetes, and alpha-Galactosylceramide ( $\alpha$-GalCer).
Importantly, the iPSCs and the parental $\mathrm{T}$ cells had identical antigen-recognition sites (CDR3 sequence) on the TCRA and TCRB genes (9). Recently, the $\mathrm{SeV}$ vectors encoding five factors (OSKM + SV40 LT antigen) were used for reprogramming various types of antigen-specific $\mathrm{T}$ cells and NKT cells, including WT1-specific T cells, LMP2-specific T cells (44), GPC3-specific T cells (57), b3a2-specific T cells (59) and $\mathrm{V} \alpha 24^{+}$invariant natural killer $\mathrm{T}$ cells $(60,61)$. 
In contrast to peripheral blood $\mathrm{T}$ cells, antigen-specific $\mathrm{T}$ cells are mainly effector memory $\mathrm{T}$ cells or central memory $\mathrm{T}$ cells, which are in the latest stage of development. Effector memory $\mathrm{T}$ cells or central memory $\mathrm{T}$ cells are prone to apoptosis when stimulated due to their short telomere length (62). Therefore, reprogramming of antigen-specific $\mathrm{T}$ cells is very technically challenging. Previous studies showed that the process requires supplementation of the OSKM factors with additional factors such as hTERT and SV40 LT antigen, which have potent antiapoptotic activity (63), and the use of MEF feeder cells $(8,9)$. It is worth noting that the hTERT and SV40 large $\mathrm{T}$ antigen are known oncogenes; upon insertion into the genome, these factors may cause tumorigenesis. Even though it is not a concern when using the $\mathrm{SeV}$ vector system because the viral RNA is diluted and removed from the cells after reprogramming, the SV40 large T antigen might increase double-stranded break (DSB)-associated mutations. Thus, other pluripotency-associated genes, such as NANOG and LIN28, were used instead of SV40 LT antigen in combination with OSKM factors for T cell reprogramming (64). This system called 6-factor (OSKM + NL) offers advantages over the conventional system (OSKM + SV40 LT) by eliminating the oncogenes and is therefore preferable for applications in ACT. In addition, T-iPSCs reprogrammed by a 6 -factor system were able to efficiently differentiate into antigen-specific $\mathrm{T}$ cells with strong cytotoxicity against cervical cancer. There is no significant difference in cytotoxicity from that of the conventional $\mathrm{T}$ iPSCs (64). Although this 6-factor system successfully generated iPSCs from the antigen-specific T cells, there are two main issues associated with using antigen-specific T cell-derived iPSCs for clinical translation, including clonal variability, which affects $\mathrm{T}$ cell differentiation potential (65), and alloreactivity (66). The study demonstrated that approximately $50 \%$ of antigenspecific $\mathrm{T}$ cell-derived iPSC clones exhibited great $\mathrm{T}$ cell differentiation potential (66). There is also a possibility that $\mathrm{T}$ cell alloreactivity will occur at $10 \%$ even in the case of HLAmatched patients $(67,68)$. Therefore, to develop an off-the-shelf product from T-iPSCs for use in an allogeneic setting, it is necessary to establish multiple clones of antigen-specific T cellderived iPSCs and screen for the best clones and other spare clones in case of alloreactivity. It was estimated that eight initial iPSC clones are sufficient to create two powerful T-iPSC clones (66). The generation and screening of eight iPSC clones are timeconsuming and expensive, especially from antigen-specific T cell sources. An alternative approach such as introducing TCR or CAR into T-iPSCs would be more practical for developing offthe-shelf ACT.

\section{GENERATION OF T CELLS FROM PLURIPOTENT STEM CELLS}

Generation of T cells from PSCs requires two essential stages. First, PSCs need appropriate signals from microenvironments to be committed toward hematopoietic stem cells (HSCs), followed by the Notch signaling for $\mathrm{T}$ cell lineage commitment (69). During the first step toward HSCs, PSCs must be differentiated into the definitive mesoderm (ME) and hemogenic endothelium (HE), which then undergoes the process known as an endothelial-to-hematopoietic transition (EHT). During EHT, the $\mathrm{HE}$ is rounded up and releases the floating cells with hematopoietic stem/progenitor cell (HSPC) markers, CD34 and CD43, into the medium $(70,71)$. Two waves of hematopoiesis occur in human embryo development, primitive and definitive. Definitive hematopoiesis can give rise to HSPCs with the potential to develop into T cells (72). The previous study demonstrated that there are no true markers to distinguish between the primitive and definitive HSPCs in the CD $34^{+}$ $\mathrm{CD}_{4} 3^{+}$populations. Therefore, identification of ME by using the phenotypes $\mathrm{KDR}^{+}$and CD235a is essential (73). After HSC induction, the differentiation process must recapitulate normal $\mathrm{T}$ cell development in the thymus where sequential expression of CD7, cytoplasmic CD3, and surface CD3 was observed, followed by TCR gene rearrangement of the $\gamma \delta$ and $\alpha \beta$ loci, respectively. This section focuses on various approaches that have been used to mimic the microenvironment in the thymus to induce mature $\mathrm{T}$ cell differentiation in vitro (Figure 2 and Table 1).

\section{Co-Culture System Using Stromal Cells}

A simple and well-known method to induce $\mathrm{T}$ cell commitment in vitro is the co-culture system with mouse stromal cells, OP9, as supporting cells for $\mathrm{T}$ cell differentiation. The OP9 cell line can be derived from the mouse bone marrow with a defect in macrophage colony-stimulating factor (MCSF) production (85). The OP9 cells can be expanded in vitro for a long time and selectively facilitate HSPC differentiation and lymphoid development (86). In 2002, Schmitt et al. developed a monolayer co-culture system for in vitro $\mathrm{T}$ cell differentiation using the OP9 cell line overexpressing Delta-like 1 (OP9-DL1), a human homolog of the Notch ligand. Co-culture of mouse HSCs with the OP9-DL1 cells induced $\mathrm{CD}^{+} \mathrm{CD}^{+}$double-positive (DP) T cells and CD8 ${ }^{+}$SP T cells (87). In 2005, La Motte-Mohs et al. published the first report of the generation of human $\mathrm{T}$ cells from CD $34^{+}$HSPCs using the OP9-DL1 co-culture system (88). A similar co-culture system has been used to generate $\mathrm{T}$ cells in vitro using the MS5 and $\mathrm{C} 3 \mathrm{H} / 10 \mathrm{~T} 1 / 2$ stromal cell lines expressing DL1. Similar to OP9-DL1, MS5 and C3H/10T1/2 stromal cells overexpressing DL1 support the differentiation of umbilical cord blood CD $34^{+}$HSPCs to $\mathrm{CD}^{+}$DN cells after 3-4 weeks of co-culture $(82,89)$. Apart from DL1, Delta-like 4 (DL4) is also known as a ligand for Notch-1 receptor (90). The in vitro study showed that DL4 overexpression in stromal cells could support T cell development in a similar manner to DL1 $(69,91)$. Although there was no significant difference between the yield of T cell differentiation when co-culturing with OP9-DL1 and OP9DL4, DL4 provided better results at physiological expression levels (92). Further study indicated that DL4 provided a 10 -fold greater Notch receptor binding affinity than DL1 (93). As a result, some studies used OP9-DL4 as a feeder cell for T cell differentiation from pluripotent stem cells $(50,52,72)$.

The first successful generation of $\mathrm{T}$ cells from iPSCs was reported in 2009 by Lei et al., where mouse iPSCs co-cultured with the OP9-DL1 cells in the presence of Flt3L and IL-7 could be differentiated into the TCR $\beta^{+} \mathrm{CD}^{+}$SP T cells. These cells 


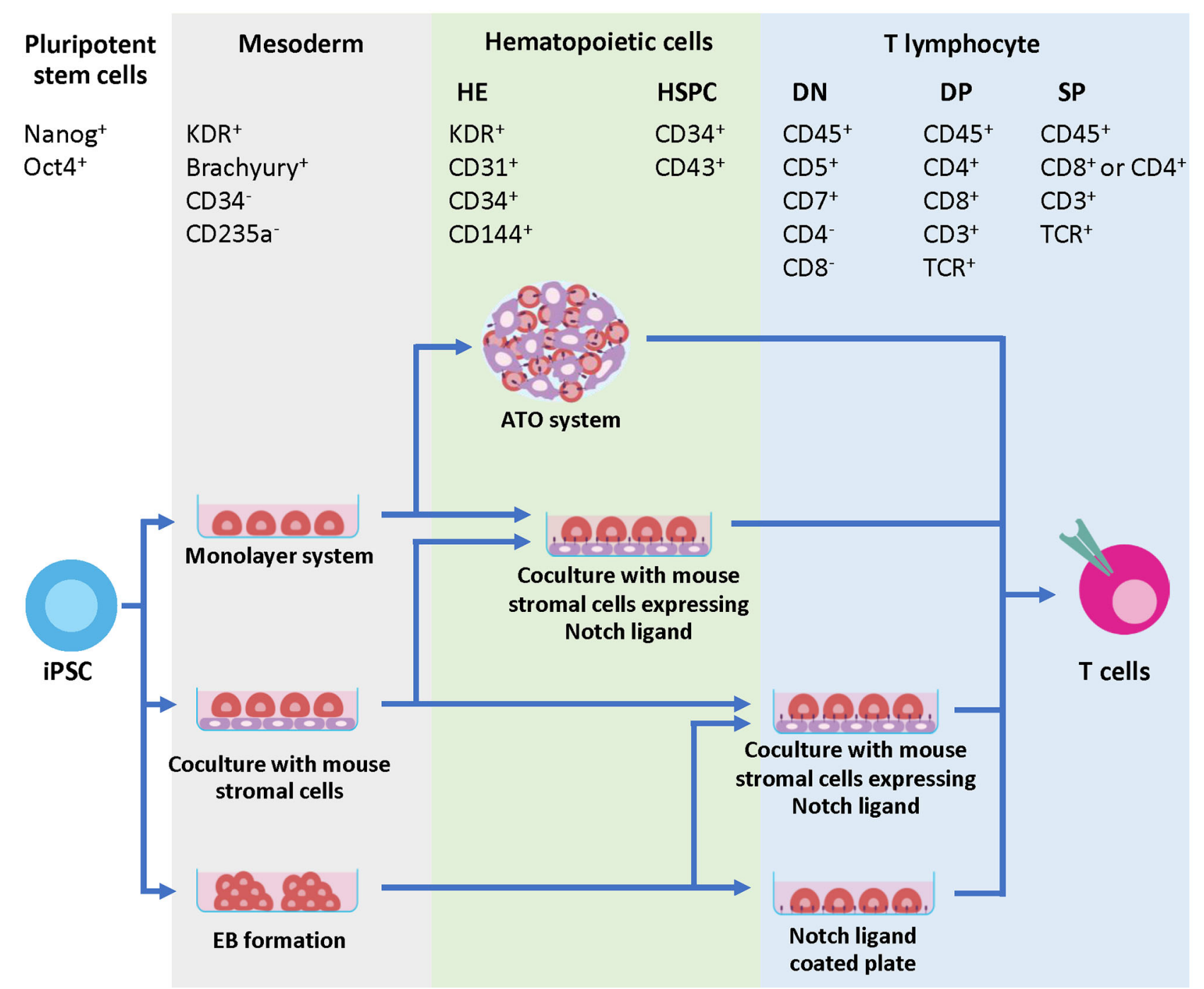

FIGURE 2 | Developmental markers during T cell differentiation and strategies to generate iPSC-derived T cells. The initial step of hematopoietic differentiation can be achieved by various protocols, including feeder-free protocols such as monolayer system, co-culture with mouse stromal cells and EB formation. During this step, the mesodermal (ME) cells expressing Brachyury and KDR are generated. The ME cells are committed further to HE, which express KDR, CD31, CD34 and CD144. During EHT process, CD43 ${ }^{+} \mathrm{HSPC}$ emerges from the HE layers. Specification of T cell lineage requires Notch signaling, which can be provided through co-culture with mouse stromal cells such as OP9-DL1 or OP9-DL4. Co-culture of iPSC-derived multipotent HSPCs with these cells in 2D or 3D system efficiently generates mature $\mathrm{T}$ cells with phenotypes $\mathrm{CD}^{+} \mathrm{CD}^{-} \mathrm{TCR}^{+}$and $\mathrm{CD}^{+}$. Alternatively, the Notch signals can be provided through a coating matrix mixture of retronectin and recombinant $\mathrm{DL} 4$ protein.

produced IL-2 and IFN- $\gamma$ after activation with anti-CD3 antibody, indicating that they are functional $\mathrm{T}$ cells. In addition, the iPSC-derived $\mathrm{T}$ cells restored the $\mathrm{T}$ cell pool in $\mathrm{Rag}^{-1-}$ mice after infusion (94). In contrast to mouse iPSCs, a single-step co-culture system with the OP9-DL1 cells has not been achieved in human iPSCs. To generate $\mathrm{T}$ cells, human iPSCs were differentiated to CD $34^{+}$HSPCs via three methods, embryoid body (EB) formation $(56,72)$, monolayer system $(80$, 95), and direct co-culture with the OP9 (96) or C3H10T1/2 cells (9). The CD34 ${ }^{+}$cells were then transferred onto the OP9-DL1 cells in the presence of Flt3L and IL-7 to further differentiate into pro-T cells, which later required TCR signal to become mature
T cells $(8,9,97)$. The mouse iPSC-derived pro-T cells can acquire TCR signals from the MHC molecule on the OP9 cells $(94,98)$. In contrast, the human iPSC-derived DP T cells cannot recognize the mouse MHC molecule on the OP9 cells, so they cannot obtain the TCR signal from co-culturing with the OP9-DL1 cells. Therefore, activation of human pro- $\mathrm{T}$ cells using anti-CD3 antibody is required to generate mature T cells $(8,9,44)$.

Although TCR $\alpha \beta^{+} \mathrm{CD}^{+} \mathrm{T}$ cells can be derived from human iPSCs, previous studies showed that human iPSCs could generate only $\mathrm{T}$ cells expressing CD8 $\alpha$ subunit (CD8 $\alpha \alpha \mathrm{T}$ cells) and high levels of innate $\mathrm{T}$ cell-related markers (such as $\mathrm{CD} 56)(8,44,56$, 82). The CD8 $\alpha \alpha \mathrm{T}$ cells differentiated from human iPSCs were 
TABLE 1 | Generation of T cells from human iPSCs.

\begin{tabular}{|c|c|c|c|c|}
\hline Cell source of iPSCs & Regenerated T cells & T cell differentiation & Functional test & Ref \\
\hline - Keratinocytes & $\begin{array}{l}\text { Randomly rearranged TCR } \\
\text { T cells }\end{array}$ & $\begin{array}{l}\text { Co-culture with OP9-DL4 } \\
\text { cells }\end{array}$ & In vitro TCR activation assay & (74) \\
\hline \multirow[t]{2}{*}{ - Myeloid cells } & WT1-TCR transduced T cells & $\begin{array}{l}\text { Co-culture with OP9-DL1 } \\
\text { cells }\end{array}$ & In vitro and in vivo specific killing assay & (57) \\
\hline & & $\begin{array}{l}\text { Culture onto DL4-coated } \\
\text { plate }\end{array}$ & In vitro and in vivo specific killing assay & (75) \\
\hline \multirow[t]{2}{*}{ - Fibroblasts } & T cells & $\begin{array}{l}\text { Co-culture with OP9-DL1 } \\
\text { cells }\end{array}$ & In vitro TCR activation assay & (78) \\
\hline & & $\begin{array}{l}\text { Co-culture with MS5-DL4 } \\
\text { cells in ATO }\end{array}$ & $\mathrm{N} / \mathrm{A}$ & (79) \\
\hline \multicolumn{5}{|l|}{ T cells } \\
\hline - PHA-activated lymphocytes & CD19-CAR transduced T cells & $\begin{array}{l}\text { Co-culture with OP9-DL1 } \\
\text { cells }\end{array}$ & In vitro and in vivo specific killing assay & (56) \\
\hline - Sorted MART-1-tetramer ${ }^{+} \mathrm{T}$ cells & MART-1-specific T cells & $\begin{array}{l}\text { Co-culture with OP9-DL1 } \\
\text { cells }\end{array}$ & In vitro specific killing assay & (66) \\
\hline \multirow[t]{3}{*}{ - Nef-specific CTL clone } & Nef-specific T cells & $\begin{array}{l}\text { Co-culture with OP9-DL1 } \\
\text { cells }\end{array}$ & In vitro specific killing assay & $(9,81)$ \\
\hline & & $\begin{array}{l}\text { Culture onto DL4-coated } \\
\text { plate }\end{array}$ & In vitro specific killing assay & (75) \\
\hline & $\begin{array}{l}\text { iC9-transduced Nef specific } \\
\text { T cells }\end{array}$ & $\begin{array}{l}\text { Co-culture with C3H10T1/2- } \\
\text { DL1 cells }\end{array}$ & In vitro specific killing assay & (82) \\
\hline \multirow[t]{2}{*}{ - GAG-specific CTL clone } & GAG-specific T cells & $\begin{array}{l}\text { Co-culture with OP9-DL1 } \\
\text { cells }\end{array}$ & In vitro specific killing assay & (81) \\
\hline & & $\begin{array}{l}\text { Culture onto DL4-coated } \\
\text { plate }\end{array}$ & In vitro specific killing assay & (75) \\
\hline - LMP2-specific CTL clone & $\begin{array}{l}\text { iC9-transduced LMP2-specific } \\
\text { T cells }\end{array}$ & $\begin{array}{l}\text { Co-culture with C3H10T1/2- } \\
\text { DL1 cells }\end{array}$ & In vitro and in vivo specific killing assay & (82) \\
\hline - WT1-specific CTL clone & WT1-specific T cells & $\begin{array}{l}\text { Co-culture with OP9-DL1 } \\
\text { cells }\end{array}$ & In vitro and in vivo specific killing assay & $\begin{array}{c}(44,76, \\
77)\end{array}$ \\
\hline - Sorted HPV16-E6 -tetramer ${ }^{+} \mathbf{T}$ cells & HPV16-E6-specific T cells & $\begin{array}{l}\text { Co-culture with C3H10T1/2- } \\
\text { DL1/4 cells }\end{array}$ & In vitro and in vivo specific killing assay & (64) \\
\hline - Sorted HPV16-E7 -tetramer ${ }^{+} \mathrm{T}$ cells & HPV16-E7-specific T cells & $\begin{array}{l}\text { Co-culture with C3H10T1/2- } \\
\text { DL1/4 cells }\end{array}$ & In vitro specific killing assay & (64) \\
\hline - b3a2-specific Th1 clone & $\begin{array}{l}\text { CD4-transduced b3a2-specific } \\
\text { T cells }\end{array}$ & $\begin{array}{l}\text { Co-culture with OP9-DL1 } \\
\text { cells }\end{array}$ & $\begin{array}{l}\text { Priming CTLs to increase specific killing } \\
\text { in vitro and in vivo }\end{array}$ & (59) \\
\hline $\begin{array}{l}\text { - Expanded TILs from colorectal } \\
\text { cancer specimens }\end{array}$ & $\begin{array}{l}\text { Multiclonal colorectal cancer- } \\
\text { specific } T \text { cells }\end{array}$ & $\begin{array}{l}\text { Culture onto DL4-coated } \\
\text { plate }\end{array}$ & In vitro and in vivo specific killing assay & (84) \\
\hline
\end{tabular}

ATO, artificial thymic organoid; b3a2, junction region of BCR-ABL p210; CAR, chimeric antigen receptor; CTL, cytotoxic T lymphocyte; DL1, delta-like 1; DL4, delta-like 4; GAG, groupspecific antigen; GPC3, glypican-3; HPV16-E6, human papillomavirus type 16 early protein 6; HPV16-E7, human papillomavirus type 16 early protein 7; iC9, inducible caspase-9; KO, knockout; $L M P 1$, latent membrane protein 1; LMP2, latent membrane protein 2; MART-1, melanoma antigen recognized by T cells 1; Nef, negative regulatory factor; PB, peripheral blood; PHA, phytohaemagg/utinin; RAG2, recombination activating gene 2; TCR, T cell receptor; Th1, Thelper type 1; TIL, tumor-infiltrating lymphocytes; WT1, Wilms' tumor 1.

different from the effector $\mathrm{T}$ cells in peripheral blood, which are CD8 $\alpha \beta$ T cells. More importantly, the regenerated CD8 $\alpha \alpha$ T cells from iPSCs showed a gene expression pattern similar to those of the innate $\mathrm{T}$ cells and exhibited a non-specific killing effect $(44,56)$.
Recently, Maeda et al. reported a novel method to generate the CD8 $\alpha \beta$ T cells from human iPSCs. During the differentiation step, the $\mathrm{CD} 4^{+} \mathrm{CD} 8^{+} \mathrm{DP}$ cells were sorted and activated using anti-CD3 antibody to generate $\mathrm{CD} 8 \alpha \beta \mathrm{T}$ cells similar to the 
effector T cells from peripheral blood (44). DNA sequencing revealed that the TCR gene of the iPSC-derived T cells and the parental $\mathrm{T}$ cell clone were completely identical, suggesting that antigen specificity of the parental $\mathrm{T}$ cells was retained in the iPSC-derived $\mathrm{T}$ cells $(8,9,44)$. Thus, in vitro cytotoxicity of regenerated $\mathrm{T}$ cells was comparable to the parental antigenspecific $\mathrm{T}$ cells (44). Moreover, the regenerated $\mathrm{T}$ cells had a rejuvenated phenotype. The iPSC-derived $\mathrm{T}$ cells established from an HIV-1-specific CTL clone could be expanded from 100 -fold to 1000 -fold within two weeks, whereas the parental T cells could be expanded up to 20 -fold. The regenerated CTLs also had a 1.5-fold longer telomere length than parental CTLs (9). Finally, the treatment with the iPSC-derived CD8 $\alpha \beta \mathrm{T}$ cells markedly delayed tumor growth in the mouse model $(44,57,82)$. Worth noting that there is no report of the successful generation of $\mathrm{CD}^{+}$helper $\mathrm{T}$ cells from iPSCs even though T-iPSC was derived from the $\mathrm{CD} 4^{+} \mathrm{T}$ cell clones (59). Antigen-specific $\mathrm{CD} 4^{+}$ $\mathrm{T}$ helper cells are essential in controlling immune reactions. These cells can amplify anti-tumor immunity by inducing the activation of tumor antigen-specific CTLs. Therefore, the absence of $\mathrm{CD}^{+} \mathrm{T}$ cells in the iPSC-derived $\mathrm{T}$ cell population may lead to insufficient control of tumor growth in patients.

\section{Artificial Thymic Organoid}

The three-dimensional (3D) structure of primary thymic stromal cells has been shown to promote positive selection and TCR rearrangement of human T cells in vitro (99). In 2017, Seet et al. developed a new method called artificial thymic organoids (ATO) system that combines the $3 \mathrm{D}$ organoid culture elements and the expandability of the stromal cell line. The ATO system requires a serum-free medium and the MS5 mouse stromal line expressing human DL1 or DL4 (MS5-DL1 or DL4 cells), which formed small $3 \mathrm{D}$ aggregates with human HSPCs by centrifugation. The $3 \mathrm{D}$ aggregates were plated onto micropore filters and cultured for six weeks. This ATO system fully recapitulated the $\mathrm{T}$ cell development, especially during the TCR rearrangement. At week 6 in ATOs, up to $20 \%$ of total cells expressed TCR $\alpha \beta$ and CD3, indicating that the cells reached the SP stage without the requirement of anti-CD3 antibody. In addition, CD8 SP T cells and CD4 SP cells isolated from ATOs produced IFN- $\gamma$ and IL-2 in response to PMA and ionomycin activation (100).

The ATO system was also applied to generate mature T cells from ESCs and iPSC (79). Firstly, the ESCs or iPSCs were induced to mesodermal lineage using BMP4, VEGF and bFGF for three days in the monolayer culture system. The cells were then dissociated into single cells and centrifuged with the MS5DL4 cells to form aggregates, which were cultured in the hematopoietic induction medium for two weeks followed by the $\mathrm{T}$ cell induction medium for 50 days. This approach generated CD8 and CD4 SP T cells, which produced IFN- $\gamma$ in response to phorbol 12-myristate 13-acetate (PMA) stimulation. Deep sequencing results revealed that the TCR $\alpha$ and $\beta$ chain rearrangement occurred during the $\mathrm{T}$ cell differentiation in the ATO system. Moreover, when using the NY-ESO-1-specific TCR engineered H1 ESC line in the ATO system, nearly $100 \%$ of the generated $\mathrm{T}$ cells expressed NY-ESO-1-specific TCR.
Transduction of NY-ESO-1-specific TCR also inhibited the rearrangement of the endogenous $\mathrm{TCR} \alpha \beta$ due to allelic exclusion of the TCR gene. Following 14 days of expansion, the ESC-derived TCR-engineered T cells expanded approximately 100-fold and displayed specific cytotoxicity against the NY-ESO-1 expressing target cells in vitro and in immunodeficient mice. Interestingly, the studies demonstrated that the ATO system could support the robust differentiation of $\mathrm{CD}^{+} \mathrm{T}$ cells $(79,101)$. However, the function and potential of $\mathrm{CD}^{+}$helper $\mathrm{T}$ cells generated from this method have not been clearly investigated.

\section{Feeder-Free Differentiation System}

Despite the success in generating T cells, the use of mouse cells as supportive feeders is not compatible with the development of clinical-grade products due to contamination of xenogeneic antigens. Although there have been many attempts to develop human feeder cells to replace the mouse cell lines, the results were unsatisfactory. Human fibroblasts or keratinocytes engineered to express DL4 were insufficient to promote the differentiation of human HSPCs to DN or DP T cells (102, 103). The first attempt to differentiate mouse HSPCs toward $T$ cells under the feeder-free system was performed using the recombinant Notch ligand DL1 fused with Fc domain of human IgG (DL1-Fc)-coated culture dish. This system enabled the generation of the DP T cells that could reconstitute mature $\mathrm{T}$ cells in the NOD/SCID mouse model (104). A similar approach to differentiate mouse HSPCs applied the DL4-Fc proteinimmobilized culture dish in the medium supplemented with SCF, Flt3L and IL-7. This system efficiently promoted the DP T cell development (105). For a scalable $\mathrm{T}$ cell differentiation system, Taqvi et al. immobilized the DL4 protein on microbeads to support $\mathrm{T}$ cell development from bone marrowderived HSPCs. The results showed that the DL4-conjugated bead system was sufficient to induce $\mathrm{T}$ cell commitment; however, most differentiated cells were committed to the B cell lineage leading to inefficient $\mathrm{T}$ cell generation (106).

Another group developed a novel feeder-free method combining the recombinant VCAM-1 with DL4 proteins. This system synergistically increased the robustness of $\mathrm{T}$ cell commitment from cord blood-derived HSPCs in a xenogeneicfree differentiation medium. After two weeks of differentiation, the differentiated cells were arrested at the DP stage with the phenotype of $\mathrm{CD} 34^{-} \mathrm{CD}^{+} \mathrm{CD}^{+}$cells. The purified $\mathrm{CD}^{+}$cells were further differentiated in vivo by intrahepatically injecting into neonatal immunocompromised mice. After 10-12 weeks post-engraftment, functional mature $\mathrm{T}$ cells were detected and circulated in the peripheral blood of the immunodeficient mice (107). Recently, Iriguchi et al. reported the success of using a feeder-free system to generate iPSC-derived mature T cells. The iPSC-derived $\mathrm{CD} 235 \mathrm{a}^{-} / \mathrm{CD} 14^{-} / \mathrm{CD} 34^{+} / \mathrm{CD} 43^{+}$cells were purified and differentiated into the functional antigen-specific $\mathrm{T}$ cell lineage under a feeder-free system using immobilized DL4 protein and retronectin. During the differentiation, $3 \times 10^{5}$ iPSCs could give rise to $6.2 \times 10^{8} \mathrm{~T}$ cells. Importantly, these iPSCderived $\mathrm{T}$ cells demonstrated the anti-tumor function in both in vitro and in vivo xenograft models (75). Similarly, Ito et al. 
demonstrated that this feeder-free protocol could be applied for the generation of tumor-specific T cells from TIL-derived iPSCs. The result showed that the regenerated $\mathrm{T}$ cells retained the $\mathrm{T}$ cell function and tumor-specific killing. Moreover, there was no additional rearrangement at either the TCR $\alpha$ or TCR $\beta$ chains of the $\mathrm{T}$ cells generated by this feeder-free protocol (84). However, these two studies still used bovine serum albumin in the medium to obtain a large number of mature $\mathrm{T}$ cells; therefore, the development of a complete xenogeneic-free condition for clinical translation of iPSC-derived $\mathrm{T}$ cells is still very challenging.

\section{ADVANCES OF IPSC-DERIVED CAR T CELLS FOR OFF-THE-SHELF ACT}

The advent of genetic engineering has created the so-called nextgeneration stem cell-based therapies with enhanced therapeutic efficiencies (108). The most promising therapeutic application in oncology to date has been CAR technology. To date, there are four CD19 CAR T cell products approved by the FDA for the treatment of relapsed or refractory large B cell lymphoma (2), and more than 900 ongoing clinical trials targeting different types of cancers (ClinicalTrials.gov). While CAR T cell therapy holds impressive clinical outcomes, many challenges hinder its applications, including insufficient autologous $\mathrm{T}$ cells due to lymphopenia in patients and a high production cost. Human iPSCs have become an attractive cell source for the generation of CAR T cells regarding their self-renewal capacity. In 2013, Themeli et al. reported the first proof-of-concept study showing that the CD19 CAR-engineered iPSCs could be used as a starting cell source for generating the functional CD19 CAR $\mathrm{T}$ cells with anti-cancer capability in a xenograft model (56). To broaden the applicability of CAR T cell therapy, many attempts have been made to generate allogeneic CAR $\mathrm{T}$ cells devoid of TCR to eliminate the risk of GvHD. These strategies employ genome editing technologies such as zinc finger nucleases (37), TALENs (40) or CRISPR/Cas9 (36) to disrupt TCR expression in primary $\mathrm{T}$ cells from healthy donors and introduce CAR specific to cancer antigens. Using CRISPR/Cas9 technology, Sadelain and colleagues generated the engineered T cells with CD19 CAR gene knockin at the TCR $\alpha$ constant (TRAC) locus. The engineered T cells lack the endogenous TCR expression and simultaneously express CD19 CAR under the control of its transcriptional regulatory elements. These engineered TRAC-encoded CD19 CAR $\mathrm{T}$ cells exhibited increased anti-tumor activities in the leukemic mouse model regarding the responses and prolonged medium survival compared to the conventional, randomly integrated CD19 CAR T cells. This study emphasized the importance of transcriptional regulation of CAR expression; the use of endogenous regulatory elements resulted in a betterdefined $\mathrm{T}$ cell product with minimized TCR-induced autoimmunity and alloreactivity as well as delayed exhaustion (36). Although the absence of TCR expression can lower the risk of GvHD, CD3 signaling from CAR can alter the T cell lineage commitment. The presence of all three $\mathrm{CD} 3 \zeta$ immunoreceptor tyrosine-based activation motifs (ITAMs) has been shown to compromise the therapeutic potency of CAR T cells. Therefore, the team modified the second and third CD3 $\zeta$ ITAMs of CAR to be non-functional (1XX) and generated CD19 1XX CAR T cells. These engineered CAR T cells have calibrated ITAM activity with similar strength of CD3 signaling from TCR, thereby exhibiting increased persistence and better therapeutic efficacy in the well-established pre-B acute lymphoblastic leukemia (B-ALL) mouse model compared to the CAR T cells with all three CD3 $\zeta$ ITAMs or other types of mutants (109).

Despite excellent results obtained in primary CAR T cells, multiplex genome engineering, quality control, and validation are technically challenging. One way to address this issue is to harness the unique characteristics of iPSCs, which are amenable to genetic manipulation and clonal validation. Fate Therapeutics has combined the iPSC technology with CAR to generate the iPSC-derived TCR-less CD19 1XX CAR T cell product to treat BALL. Upon T cell differentiation, the iPSCs harboring TRACCD19 1XX CAR could give rise to the highest $\mathrm{CD} 4^{+} \mathrm{CD} 8^{+} \mathrm{DP}$ population compared to other types of iPSC-derived CAR T cells. Importantly, the $\mathrm{CD} 4^{+} \mathrm{CD} 8^{+} \mathrm{DP}$ cells could be efficiently differentiated into CD8 $\alpha \beta$ SP CAR T cells (110). This novel platform, so-called "the first-of-kind off-the-shelf hiPSC-derived CAR19 T cell product FT819" was manufactured under the current Good Manufacturing Practice (cGMP) compliance and applied in the pre-clinical study. The in vivo leukemia xenograft mouse studies also showed that FT819 could control tumor burden and prolong survival rate similar to those of the CD19 CAR $T$ cells $(111,112)$. In addition, the mixed lymphocyte reactions performed with HLA-mismatched peripheral blood mononuclear cells (PBMCs) confirmed the lack of alloreactivity, thereby eliminating the risk of GvHD (113). Recently, Phase I multicenter trial of FT819 has been initiated in up to 300 patients with relapsed/refractory B cell malignancies. Various FT819 dose levels ranging from 30 to 900 million cells will be tested to find the recommended Phase II dose. Three treatment regimens for each type of cancer will be included: Regimen A, FT819 will be given as a single dose; Regimen B, FT819 will be given as a single dose combining with IL-2; and Regimen C, FT819 will be given at three fractionated doses (114).

Besides the risk of GvHD, graft rejection by the recipient's immune cells is another concern. Several groups have generated universal or hypoimmunogenic iPSC lines by eliminating HLA class Ia (HLA-A, -B, and -C) and class II molecules to avoid immune rejection by CD8 T cells and CD4 T cells, respectively, and introducing HLA class Ib (HLA-G or HLA-E) or immune checkpoint molecules (PD-L1 or CD47) to prevent NK cellmediated lysis or phagocytosis by macrophages (115-122). To date, the main challenge for translating these approaches is how to avoid NK cell-mediated lysis. This can be achieved by suppressing the activating signals or promoting the inhibitory signals. However, there are diverse activating and inhibitory receptors expressed on $\mathrm{NK}$ cells of each individual; thus, targeting multiple receptors is necessary to completely prevent the NK cell attacks $(123,124)$. Previous studies showed that 
expression of HLA-E in the HLA-null iPSC-derived CD45 ${ }^{+}$cells (116) and iPSC-derived retinal pigment epithelial cells (125) could inhibit NK cell-mediated lysis through the interaction with CD94/NKG2A receptors. However, it was shown that approximately $50 \%$ of NK cells express NKG2A receptor (126); therefore, HLA-E expressing cells may still be a target for $\mathrm{NKG}^{-} \mathrm{A}^{-} \mathrm{NK}$ cells (122). More recently, Wang et al. took a step forward by knocking out poliovirus receptor (PVR) or CD155, a ligand for NK cell-activating receptor DNAM-1, in the HLA-E-transduced, HLA-I- and HLA-II-null iPSCs. Upon differentiation toward cytotoxic $\mathrm{T}$ cells, the engineered cells could reduce the activation of DNAM- $1^{+} \mathrm{NK}$ cells, consisting of both $\mathrm{NKG}_{2} \mathrm{~A}^{+}$and $\mathrm{NKG} 2 \mathrm{~A}^{-}$populations, and persisted longer than the HLA-intact iPSC-derived T cells in vitro and in vivo in the presence of allogeneic immunity (119). Therefore, engineering multiple inhibitory/activating signals could lead to a more effective escape from NK cells making the iPSC-derived T cells applicable to a larger number of patients.

Apart from the modification of TCR and/or HLA genes and the introduction of CAR for the generation of universal iPSC-derived CAR T cells, there are attempts to engineer the iPSCs with other molecules to expand the potential of adoptive iPSC-derived CAR T cell therapy. One feature is the expression of a high-affinity, non-cleavable form of antibody receptor CD16 (hnCD16), which allows the scientists to adjust the specificity of the $\mathrm{T}$ cell killing through antibody-dependent cellular-cytotoxicity (ADCC) by adding a monoclonal antibody. For example, the iPSC-derived CD19 CAR-hnCD16 T cells could efficiently recognize and kill both $\mathrm{CD}_{1} 9^{+} \mathrm{CD} 20^{+}$and $\mathrm{CD} 19$ $\mathrm{CD} 20^{+}$tumor cells when combined with anti-CD20 monoclonal antibody (Rituxan) (113). Therefore, this strategy could be applied to target multiple cancer antigens. Another approach to increase the persistence and therapeutic efficacy of iPSCderived CAR $\mathrm{T}$ cells is to engineer a signaling-fusion complex such as IL-7 receptor fusion (IL-7RF), which is a fusion protein of IL-7 receptor and its ligand; therefore, IL-7RF can generate IL7 signal by itself without exogenous IL-7 support. The addition of IL-7RF led to higher anti-tumor activity compared to the control group in both the in vitro and in vivo studies (127).

In 2020, a novel TCR (MC.7.G5) was discovered using a genome-wide CRISPR-Cas9 screening. This TCR exhibits a pancancer cell recognition potential via the invariant monomorphic MHC class I-related protein MR1 molecule. T cells expressing the MR1-restricted TCR (MR1-TCR) could kill a broad range of cancer cells independently of classical MHC molecules. Importantly, these MR1-TCR T cells are inert when being cocultured with healthy cells from various tissues (128). The discovery of the MR1-TCR offers therapeutic opportunities for many cancers in all individuals. Recently, Nguyen et al. demonstrated the feasibility of the MR1-TCR in the engineered iPSCs, which also express CD19 CAR and hnCD16. Upon T cell differentiation, the engineered iPSC-derived $\mathrm{T}$ cells could recognize multiple hematological and solid tumor cell lines. Expression of hnCD16 also enhanced killing of $\mathrm{CD}_{2} 0^{+}$Raji cells when combined with Rituximab or HER2 ${ }^{+}$SKOV3 cells in the presence of anti-HER2 monoclonal antibody (Herceptin).
Besides, the CD19 CAR T cells expressing either MR1-TCR or hnCD16 could eliminate CD19-negative lymphoma cells in the co-culture system (129). Altogether, these studies demonstrate the feasibility of iPSCs as a potential renewable cell source of CAR T cells and pave the way for developing off-the-shelf CAR T cell products with enhanced therapeutic efficacy (Figure 3).

\section{CHALLENGES AND FUTURE PERSPECTIVES}

Adoptive immunotherapy using CAR T cells has shown great success in patients with relapse and refractory $B$ cell malignancies. While autologous $\mathrm{T}$ cells provide safety regarding lower risks of adverse side effects such as GvHD, the manufacturing process takes too long for some patients. In addition, the $\mathrm{T}$ cell doses largely depend on each individual. This becomes challenging in patients with a low number of $\mathrm{T}$ cells. Ex vivo expansion of T cells can result in T cell exhaustion, which reduces effector functions. These issues limit the clinical utility. Recently, the treatment using allogeneic $\mathrm{T}$ cells from healthy donors has gained more interest since the cells can be prepared and comprehensively validated in advance as off-the-shelf cell products, which can eventually lower the manufacturing cost and time (130). Advances in genome editing technologies have generated various types of engineered $\mathrm{T}$ cells with enhanced antigen specificity and persistence, and reduced alloreactivity so the cells can be applied to patients with broader histocompatibility. At present, several clinical trials are being performed to test the safety and efficacy of these engineered T cells, as reviewed in (131).

Meanwhile, iPSCs have been used as a starting cell source for the generation of immune cells for next-generation adoptive immunotherapy. The iPSCs offer advantages such as unlimited proliferation and the ability to differentiate into various cell types, including $\mathrm{T}$ cells and $\mathrm{NK}$ cells, and ease of multiplexed genome editing. With these properties, the engineered iPSC clones can be isolated, expanded, differentiated, functionally validated and banked in advance (132). However, there are several manufacturing and regulatory hurdles that need to be overcome. For example, the reprogramming methods must be integration-free to avoid potential mutagenesis and transgene reactivation. The process must be performed under cGMP standards (133). At the Center for iPS Cell Research and Application (CiRA), Kyoto University, Japan, the clinical-grade clonal master cell banks were derived from peripheral blood or umbilical cord blood of HLA-homozygous healthy volunteers using episomal plasmid reprogramming (134). Before the secondary cell stock can be used, it is essential to ensure that the cells exhibit normal karyotype and the residual plasmids were absent. Genomic integrity associated with reprogramming and prolonged culture of the established iPSC line, such as chromosomal alterations, copy number variations (CNV), and indel mutations, should be determined using whole-exome sequencing and SNP array, or whole-genome sequencing (134, 135). In addition, if the iPSCs are genetically engineered using 


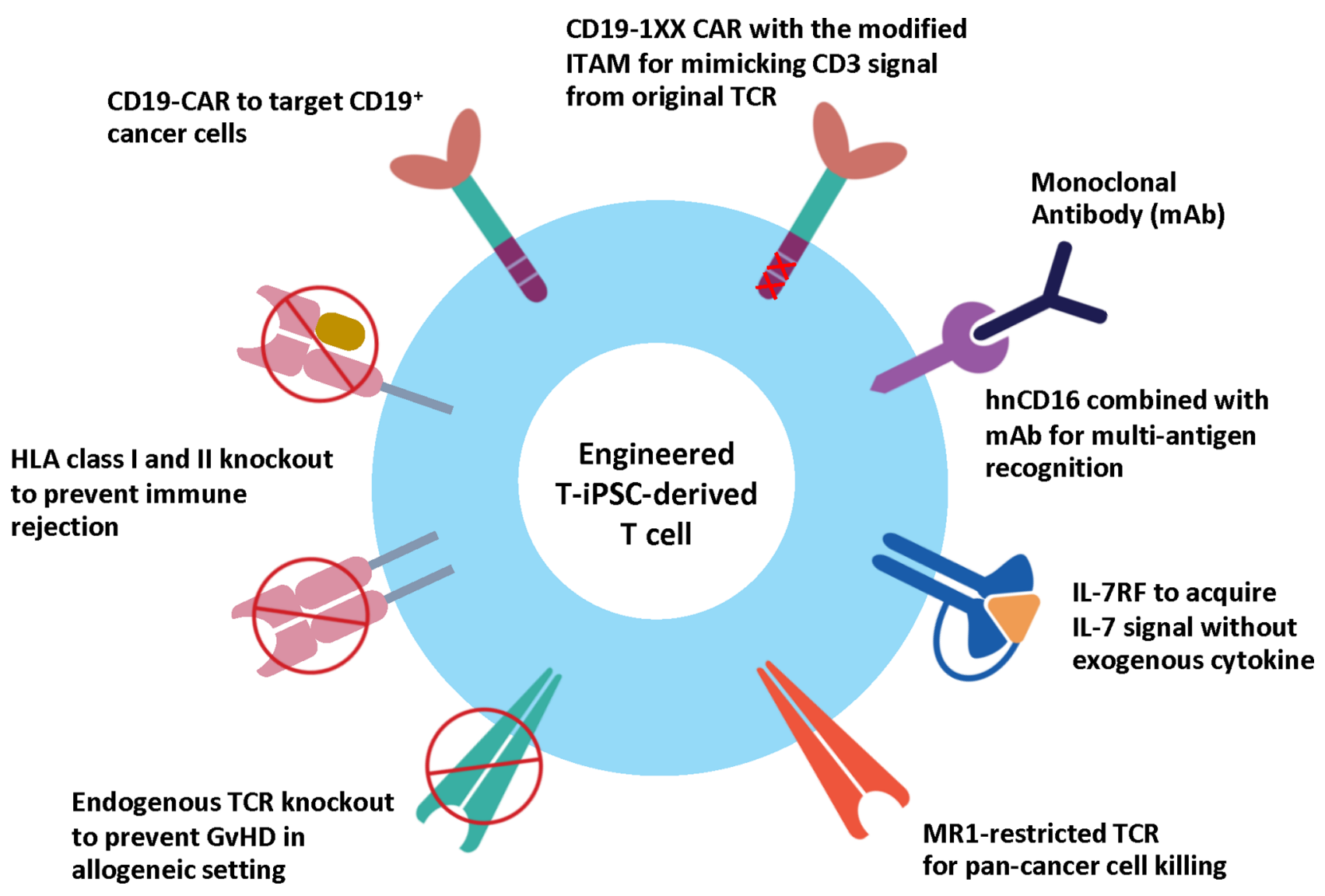

FIGURE 3 | Engineered T-iPSC-derived T cells for next-generation ACT. Genome editing technologies can be used to eliminate the endogenous TCR to reduce the risk of graft-versus-host-disease (GvHD) or HLA molecules to reduce the risk of immune rejection for allogeneic use, or to introduce CAR to specifically target cancer cells. However, the conventional CAR with three ITAM motifs generates higher CD3 signals than endogenous TCR and results in altered T cell differentiation of iPSCs. CD19-1XX CAR construct is the novel CAR construct with mutated second and third ITAM motifs to reduce the CD3 signal. Apart from CAR, the iPSC-derived T cells can be modified to express MR1-restricted TCR to target a wide range of cancer cells. Other strategies to enhance cytotoxic activity and persistence include the expression of hnCD16 and IL-7 RF.

the CRISPR/Cas9 system, the off-target activity from the incorrect binding of sgRNA can often occur and result in insertion-deletion (indel) mutations. Therefore, after clonal selection, it is recommended to conduct the whole-genome sequencing and careful screening of the clones for sterility, mycoplasma, and endotoxin before they are applied in clinics (136).

Apart from the quality control of the established iPSC line, the quality control of the final product, in this case, differentiated $\mathrm{T}$ cells, must be performed to evaluate the phenotype and function both in vitro and in pre-clinical studies. The differentiation protocol to generate $\mathrm{T}$ cells should be developed under a xenogeneic-free system i.e., without serum supplementation or mouse stromal cells as supportive feeders. To date, most published protocols still rely on the use of xenogeneic feeder cells. Although a recent study reported the use of the immobilized-DL-4 protein to generate clinically relevant functional iPSC-derived CD $8 \alpha \beta^{+}$CAR-T cells (iCART), the therapeutic efficacy of iCART cells was more inferior than that of primary CART cells. This was due to the absence of $\mathrm{CD} 4^{+} \mathrm{T}$ cells, which also play an important role in the anti-tumor effect of CAR T cell therapy (75). While the 3D ATO platform could produce $\mathrm{CD}^{+}{ }^{+} \mathrm{T}$ cells, this approach still requires co-culture with the mouse MS5-DLL4 cell line (137). Therefore, the generation of clinical-scale iPSC-derived functional $\mathrm{T}$ cells consisting of both $\mathrm{CD}^{+}$and $\mathrm{CD}^{+}$cells is necessary (138). Furthermore, the risk of tumor formation after transplantation due to residual pluripotent cells is the most significant concern. Cell sorting should be done to eliminate the contaminating cells as part of a quality check. In addition, the tumorigenicity test using immunodeficient mice such as NOG mice is also required to ensure that the transplanted cells are safe for clinical translation $(133,139)$. It is worth noting that the cell manufacturing process is far more sophisticated and complicated than pharmaceutical products. Altogether, these challenges are the main hurdles that slow down the clinical translation of iPSC-derived cell products.

As mentioned earlier, genome editing technology has been applied to generate universal iPSC-derived $\mathrm{T}$ cells. The removal 
of HLA-I can pose a potential safety risk. If the transplanted cells are virally infected or transformed into a tumor, they would not be recognized by the immune cells. Therefore, the solution to these problems is to introduce a suicide gene such as inducible Caspase 9 (iCas9) into the cells. Upon activation by a specific chemical inducer of dimerization (CID), the caspase cascade is induced, and the cells rapidly undergo apoptosis (140). This suicide system was previously tested in the T-iPSCs, and the results showed that the cytotoxic $\mathrm{T}$ cells derived from the iC9expressing T-iPSCs were effective against EBV-induced tumors in the mouse model. Upon administration with CID, the iC9 system was activated, leading to apoptosis of CTLs. The suicide system can also be exploited to eliminate contaminating iPSCs or tumors derived from iPSCs as well as preventing adverse events such as GvHD, cytokine release syndrome, "on-target, off-tumor toxicities" in iPSC-derived T cell therapy (82).

Other concerns observed in CAR T cell therapy could also be considered for developing iPSC-derived $\mathrm{T}$ cells. The therapeutic efficacy of CAR T cell therapy mainly depends on the identification of the tumor-associated antigens or neoantigens that are expressed only on the tumor cells and not on the healthy cells. The ideal target antigen will have fewer adverse effects from "on-target, offtumor toxicities" (141). Furthermore, in solid tumors, the immunosuppressive tumor microenvironments (TME) represent a significant barrier that impairs the function of CAR T cells. Several approaches have been applied to alter the TME from immunosuppressive to pro-inflammatory, including the use of a conditioning regimen prior to $\mathrm{T}$ cell infusion, small molecules to interfere with immunosuppressive cells, and blocking antibodies such as anti-PD-1 scFv to inhibit immune checkpoints $(142,143)$ as well as engineering CAR to express cytokine receptor or to secrete cytokines such as IL-12, IL-18, IL-15 to increase T cell persistence and anti-tumor efficacy (141, 144-147). To date, the CAR T cell therapy for solid tumors in clinical trials has not been effective since $\mathrm{T}$ cells cannot penetrate and survive in the TME. To overcome these hurdles, CAR platforms in other immune cells have been explored. One of which is macrophages that have abilities to penetrate the TME, perform phagocytosis and antigen presentation, and interact with other immune cells in the TME. Recently, Zhang et al. incorporated CD19-specific CAR into iPSCs and differentiated them into macrophages (CAR-iMac). Upon activation with leukemia and lymphoma cells, the CAR-iMAC were polarized toward the pro-inflammatory M1 subtype and able

\section{REFERENCES}

1. Neelapu SS, Tummala S, Kebriaei P, Wierda W, Gutierrez C, Locke FL, et al. Chimeric Antigen Receptor T-Cell Therapy-Assessment and Management of Toxicities. Nat Rev Clin Oncol (2018) 15(1):47-62. doi: 10.1038/ nrclinonc.2017.148

2. Asher M. FDA Approves Fourth CAR-T Cell Therapy. Nat Rev Drug Discovery (2021) 20(3):166. doi: 10.1038/d41573-021-00031-9

3. Themeli M, Riviere I, Sadelain M. New Cell Sources for T Cell Engineering and Adoptive Immunotherapy. Cell Stem Cell (2015) 16(4):357-66. doi: 10.1016/j.stem.2015.03.011

4. Karagiannis P, Iriguchi S, Kaneko S. Reprogramming Away From the Exhausted T Cell State. Semin Immunol (2016) 28(1):35-44. doi: 10.1016/ j.smim.2015.10.007 to phagocytose the tumor cells in an antigen-dependent manner. Therefore, combining iPSC-derived CAR T cells and CAR-iMac may provide an improved outcome in patients with the heavy burden of solid tumors (148).

\section{CONCLUSION}

Advances in iPSC and genome editing technologies offer great promise toward the next-generation ACT where the iPSCs can be engineered to have a more potent cytotoxic function, increased persistence, and less immunogenicity. The iPSC-derived CAR T cells can be prepared and validated in advance as off-the-shelf products to be administered to a large number of cancer patients. Although several hurdles and challenges remain to be overcome, this strategy will provide an infinite supply of true off-the-shelf cell products for cancer immunotherapy.

\section{AUTHOR CONTRIBUTIONS}

All authors contributed to the article and approved the submitted version.

\section{FUNDING}

This study was supported by grants from the Thailand Research Fund (grant no. RSA6280090), the Program Management Unit for Human Resources \& Institutional Development, Research and Innovation (grant no. B05F630080), the Siriraj Research Fund, Faculty of Medicine Siriraj Hospital, Mahidol University (grant number (IO) R016234002) and Mahidol University. $\mathrm{RN}$ is supported by the Development and Promotion of Science and Technology Talents Project. MW is supported by Chalermphrakiat Grant, Faculty of Medicine Siriraj Hospital, Mahidol University.

\section{ACKNOWLEDGMENTS}

The authors thank all members of Siriraj Center of Regenerative Medicine for valuable suggestions.

5. Minagawa A, Kaneko S. Rise of iPSCs as a Cell Source for Adoptive Immunotherapy. Hum Cell (2014) 27(2):47-50. doi: 10.1007/s13577-0140089-8

6. Okita K, Yamakawa T, Matsumura Y, Sato Y, Amano N, Watanabe A, et al. An Efficient Nonviral Method to Generate Integration-Free HumanInduced Pluripotent Stem Cells From Cord Blood and Peripheral Blood Cells. Stem Cells (2013) 31(3):458-66. doi: 10.1002/stem.1293

7. Takahashi K, Okita K, Nakagawa M, Yamanaka S. Induction of Pluripotent Stem Cells From Fibroblast Cultures. Nat Protoc (2007) 2(12):3081-9. doi: 10.1038/nprot.2007.418

8. Vizcardo R, Masuda K, Yamada D, Ikawa T, Shimizu K, Fujii S-I, et al. Regeneration of Human Tumor Antigen-Specific T Cells From iPSCs Derived From Mature CD8+ T Cells. Cell Stem Cell (2013) 12(1):31-6. doi: $10.1016 /$ j.stem.2012.12.006 
9. Nishimura T, Kaneko S, Kawana-Tachikawa A, Tajima Y, Goto H, Zhu D, et al. Generation of Rejuvenated Antigen-Specific T Cells by Reprogramming to Pluripotency and Redifferentiation. Cell Stem Cell (2013) 12(1):114-26. doi: 10.1016/j.stem.2012.11.002

10. Zhu H, Lai YS, Li Y, Blum RH, Kaufman DS. Concise Review: Human Pluripotent Stem Cells to Produce Cell-Based Cancer Immunotherapy. Stem Cells (2018) 36(2):134-45. doi: 10.1002/stem.2754

11. Torikai H, Cooper LJ. Translational Implications for Off-The-Shelf Immune Cells Expressing Chimeric Antigen Receptors. Mol Ther (2016) 24(7):117886. doi: $10.1038 / \mathrm{mt} .2016 .106$

12. Laiosa CV, Stadtfeld M, Graf T. Determinants of Lymphoid-Myeloid Lineage Diversification. Annu Rev Immunol (2006) 24:705-38. doi: 10.1146/annurev.immunol.24.021605.090742

13. Harman BC, Jenkinson EJ, Anderson G. Microenvironmental Regulation of Notch Signalling in T Cell Development. Semin Immunol (2003) 15(2):91-7. doi: 10.1016/S1044-5323(03)00005-8

14. Lind EF, Prockop SE, Porritt HE, Petrie HT. Mapping Precursor Movement Through the Postnatal Thymus Reveals Specific Microenvironments Supporting Defined Stages of Early Lymphoid Development. J Exp Med (2001) 194(2):127-34. doi: 10.1084/jem.194.2.127

15. Klein L, Kyewski B, Allen PM, Hogquist KA. Positive and Negative Selection of the T Cell Repertoire: What Thymocytes See (and Don't See). Nat Rev Immunol (2014) 14(6):377-91. doi: 10.1038/nri3667

16. Singer A, Adoro S, Park JH. Lineage Fate and Intense Debate: Myths, Models and Mechanisms of CD4- Versus CD8-Lineage Choice. Nat Rev Immunol (2008) 8(10):788-801. doi: 10.1038/nri2416

17. Palmer E, Naeher D. Affinity Threshold for Thymic Selection Through a TCell Receptor-Co-Receptor Zipper. Nat Rev Immunol (2009) 9(3):207-13. doi: $10.1038 /$ nri2469

18. Hinterberger M, Aichinger M, Da Costa OP, Voehringer D, Hoffmann R, Klein L. Autonomous Role of Medullary Thymic Epithelial Cells in Central CD4+ T Cell Tolerance. Nat Immunol (2010) 11(6):512-9. doi: 10.1038/ ni. 1874

19. Ahmed R, Gray D. Immunological Memory and Protective Immunity: Understanding Their Relation. Science (1996) 272(5258):54-60. doi: 10.1126/science.272.5258.54

20. Muul LM, Spiess PJ, Director EP, Rosenberg SA. Identification of Specific Cytolytic Immune Responses Against Autologous Tumor in Humans Bearing Malignant Melanoma. J Immunol (1987) 138(3):989-95.

21. Rosenberg SA, Yannelli JR, Yang JC, Topalian SL, Schwartzentruber DJ, Weber JS, et al. Treatment of Patients With Metastatic Melanoma With Autologous Tumor-Infiltrating Lymphocytes and Interleukin 2. J Natl Cancer Institute (1994) 86(15):1159-66. doi: 10.1093/jnci/86.15.1159

22. Dudley ME, Wunderlich JR, Yang JC, Hwu P, Schwartzentruber DJ, Topalian SL, et al. A Phase I Study of Nonmyeloablative Chemotherapy and Adoptive Transfer of Autologous Tumor Antigen-Specific T Lymphocytes in Patients With Metastatic Melanoma. J Immunother (Hagerstown Md: 1997) (2002) 25(3):243. doi: 10.1097/00002371200205000-00007

23. Wrzesinski C, Paulos CM, Kaiser A, Muranski P, Palmer DC, Gattinoni L, et al. Increased Intensity Lymphodepletion Enhances Tumor Treatment Efficacy of Adoptively Transferred Tumor-Specific T Cells. J Immunother (Hagerstown Md: 1997) (2010) 33(1):1. doi: 10.1097/CJI.0b013e3181b88ffc

24. Tran E, Turcotte S, Gros A, Robbins PF, Lu Y-C, Dudley ME, et al. Cancer Immunotherapy Based on Mutation-Specific CD4+ T Cells in a Patient With Epithelial Cancer. Science (2014) 344(6184):641-5. doi: 10.1126/science. 1251102

25. Johnson LA, Morgan RA, Dudley ME, Cassard L, Yang JC, Hughes MS, et al. Gene Therapy With Human and Mouse T-Cell Receptors Mediates Cancer Regression and Targets Normal Tissues Expressing Cognate Antigen. Blood (2009) 114(3):535-46. doi: 10.1182/blood-2009-03-211714

26. Morgan RA, Dudley ME, Wunderlich JR, Hughes MS, Yang JC, Sherry RM, et al. Cancer Regression in Patients After Transfer of Genetically Engineered Lymphocytes. Science (2006) 314(5796):126-9. doi: 10.1126/science.1129003

27. Robbins PF, Morgan RA, Feldman SA, Yang JC, Sherry RM, Dudley ME, et al. Tumor Regression in Patients With Metastatic Synovial Cell Sarcoma and Melanoma Using Genetically Engineered Lymphocytes Reactive With NY-ESO-1. J Clin Oncol (2011) 29(7):917. doi: 10.1200/JCO.2010.32.2537
28. Masuda K, Hiraki A, Fujii N, Watanabe T, Tanaka M, Matsue K, et al. Loss or Down-Regulation of HLA Class I Expression at the Allelic Level in Freshly Isolated Leukemic Blasts. Cancer Sci (2007) 98(1):102-8. doi: 10.1111/ j.1349-7006.2006.00356.x

29. Menon AG, Morreau H, Tollenaar RA, Alphenaar E, van Puijenbroek M, Putter H, et al. Down-Regulation of HLA-A Expression Correlates With a Better Prognosis in Colorectal Cancer Patients. Lab Invest (2002) 82 (12):1725-33. doi: 10.1097/01.LAB.0000043124.75633.ED

30. Gross G, Eshhar Z. Endowing T Cells With Antibody Specificity Using Chimeric T Cell Receptors. FASEB J (1992) 6(15):3370-8. doi: 10.1096/ fasebj.6.15.1464371

31. Gross G, Waks T, Eshhar Z. Expression of Immunoglobulin-T-Cell Receptor Chimeric Molecules as Functional Receptors With Antibody-Type Specificity. Proc Natl Acad Sci (1989) 86(24):10024-8. doi: 10.1073/ pnas.86.24.10024

32. Maus MV, Fraietta JA, Levine BL, Kalos M, Zhao Y, June CH. Adoptive Immunotherapy for Cancer or Viruses. Annu Rev Immunol (2014) 32:189225. doi: 10.1146/annurev-immunol-032713-120136

33. Lyman GH, Nguyen A, Snyder S, Gitlin M, Chung KC. Economic Evaluation of Chimeric Antigen Receptor T-Cell Therapy by Site of Care Among Patients With Relapsed or Refractory Large B-Cell Lymphoma. JAMA Netw Open (2020) 3(4):e202072-e. doi: 10.1001/jamanetworkopen.2020.2072

34. Fiorenza S, Ritchie DS, Ramsey SD, Turtle CJ, Roth JA. Value and Affordability of CAR T-Cell Therapy in the United States. Bone Marrow Transplant (2020) 55(9):1706-15. doi: 10.1038/s41409-020-0956-8

35. Leen AM, Bollard CM, Mendizabal AM, Shpall EJ, Szabolcs P, Antin JH, et al. Multicenter Study of Banked Third-Party Virus-Specific T Cells to Treat Severe Viral Infections After Hematopoietic Stem Cell Transplantation. Blood (2013) 121(26):5113-23. doi: 10.1182/blood-2013-02-486324

36. Eyquem J, Mansilla-Soto J, Giavridis T, van der Stegen SJ, Hamieh M, Cunanan KM, et al. Targeting a CAR to the TRAC Locus With CRISPR/ Cas9 Enhances Tumour Rejection. Nature (2017) 543(7643):113-7. doi: 10.1038/nature21405

37. Torikai H, Reik A, Liu PQ, Zhou Y, Zhang L, Maiti S, et al. A Foundation for Universal T-Cell Based Immunotherapy: T Cells Engineered to Express a CD19-Specific Chimeric-Antigen-Receptor and Eliminate Expression of Endogenous TCR. Blood (2012) 119(24):5697-705. doi: 10.1182/blood2012-01-405365

38. Bridgeman JS, Hawkins RE, Bagley S, Blaylock M, Holland M, Gilham DE. The Optimal Antigen Response of Chimeric Antigen Receptors Harboring the CD3zeta Transmembrane Domain Is Dependent Upon Incorporation of the Receptor Into the Endogenous TCR/CD3 Complex. J Immunol (Baltimore Md 1950) (2010) 184(12):6938-49. doi: 10.4049/jimmunol. 0901766

39. Poirot L, Philip B, Schiffer-Mannioui C, Le Clerre D, Chion-Sotinel I, Derniame S, et al. Multiplex Genome-Edited T-Cell Manufacturing Platform for "Off-The-Shelf" Adoptive T-Cell Immunotherapies. Cancer Res (2015) 75(18):3853-64. doi: 10.1158/0008-5472.Can-14-3321

40. Qasim W, Zhan H, Samarasinghe S, Adams S, Amrolia P, Stafford S, et al. Molecular Remission of Infant B-ALL After Infusion of Universal TALEN Gene-Edited CAR T Cells. Sci Trans Med (2017) 9(374). doi: 10.1126/ scitranslmed.aaj2013

41. Depil S, Duchateau P, Grupp SA, Mufti G, Poirot L. 'Off-the-Shelf Allogeneic CAR T Cells: Development and Challenges. Nat Rev Drug Discovery (2020) 19(3):185-99. doi: 10.1038/s41573-019-0051-2

42. Benjamin R, Graham C, Yallop D, Jozwik A, Mirci-Danicar OC, Lucchini G, et al. Genome-Edited, Donor-Derived Allogeneic Anti-CD19 Chimeric Antigen Receptor $\mathrm{T}$ Cells in Paediatric and Adult B-Cell Acute Lymphoblastic Leukaemia: Results of Two Phase 1 Studies. Lancet (London England) (2020) 396(10266):1885-94. doi: 10.1016/s0140-6736 (20)32334-5

43. DiNofia AM, Grupp SA. Will Allogeneic CAR T Cells for CD19(+) Malignancies Take Autologous CAR T Cells 'Off the Shelf? Nat Rev Clin Oncol (2021) 18(4):195-6. doi: 10.1038/s41571-021-00485-1

44. Maeda T, Nagano S, Ichise H, Kataoka K, Yamada D, Ogawa S, et al. Regeneration of CD8alphabeta T Cells From T-Cell-Derived iPSC Imparts Potent Tumor Antigen-Specific Cytotoxicity. Cancer Res (2016) 76 (23):6839-50. doi: 10.1158/0008-5472.can-16-1149 
45. Hew M, O'Connor K, Edel MJ, Lucas M. The Possible Future Roles for iPSCDerived Therapy for Autoimmune Diseases. J Clin Med (2015) 4(6):1193206. doi: $10.3390 / \mathrm{jcm} 4061193$

46. Dejaco C, Duftner C, Grubeck-Loebenstein B, Schirmer M. Imbalance of Regulatory T Cells in Human Autoimmune Diseases. Immunology (2006) 117(3):289-300. doi: 10.1111/j.1365-2567.2005.02317.x

47. Tang Q, Adams JY, Penaranda C, Melli K, Piaggio E, Sgouroudis E, et al. Central Role of Defective Interleukin-2 Production in the Triggering of Islet Autoimmune Destruction. Immunity (2008) 28(5):687-97. doi: 10.1016/ j.immuni.2008.03.016

48. Haque R, Lei F, Xiong X, Bian Y, Zhao B, Wu Y, et al. Programming of Regulatory T Cells From Pluripotent Stem Cells and Prevention of Autoimmunity. J Immunol (2012) 189(3):1228. doi: 10.4049/jimmunol.1200633

49. Haque M, Lei F, Xiong X, Das JK, Ren X, Fang D, et al. Stem Cell-Derived Tissue-Associated Regulatory T Cells Suppress the Activity of Pathogenic Cells in Autoimmune Diabetes. JCI Insight (2019) 4(7):e126471. doi: $10.1172 /$ jci.insight.126471

50. Chang CW, Lai YS, Lamb LSJr., Townes TM. Broad T-Cell Receptor Repertoire in T-Lymphocytes Derived From Human Induced Pluripotent Stem Cells. PloS One (2014) 9(5):e97335. doi: 10.1371/journal.pone.0097335

51. Menon T, Firth AL, Scripture-Adams DD, Galic Z, Qualls SJ, Gilmore WB, et al. Lymphoid Regeneration From Gene-Corrected SCID-X1 Subject-Derived iPSCs. Cell Stem Cell (2015) 16(4):367-72. doi: 10.1016/j.stem.2015.02.005

52. Brauer PM, Pessach IM, Clarke E, Rowe JH, Ott de Bruin L, Lee YN, et al. Modeling Altered T-Cell Development With Induced Pluripotent Stem Cells From Patients With RAG1-Dependent Immune Deficiencies. Blood (2016) 128(6):783-93. doi: 10.1182/blood-2015-10-676304

53. Seki T, Yuasa S, Fukuda K. Derivation of Induced Pluripotent Stem Cells From Human Peripheral Circulating T Cells. Curr Protoc Stem Cell Biol (2011) 18(1):4A. 3.1-4A. 3.9. doi: 10.1002/9780470151808.sc04a03s18

54. Seki T, Yuasa S, Fukuda K. Generation of Induced Pluripotent Stem Cells From a Small Amount of Human Peripheral Blood Using a Combination of Activated T Cells and Sendai Virus. Nat Protoc (2012) 7(4):718. doi: 10.1038/ nprot.2012.015

55. Kishino Y, Seki T, Fujita J, Yuasa S, Tohyama S, Kunitomi A, et al. Derivation of Transgene-Free Human Induced Pluripotent Stem Cells From Human Peripheral T Cells in Defined Culture Conditions. PloS One (2014) 9(5):e97397. doi: 10.1371/journal.pone.0097397

56. Themeli M, Kloss CC, Ciriello G, Fedorov VD, Perna F, Gonen M, et al. Generation of Tumor-Targeted Human T Lymphocytes From Induced Pluripotent Stem Cells for Cancer Therapy. Nat Biotechnol (2013) 31 (10):928-33. doi: 10.1038/nbt.2678

57. Minagawa A, Yoshikawa T, Yasukawa M, Hotta A, Kunitomo M, Iriguchi S, et al. Enhancing T Cell Receptor Stability in Rejuvenated iPSC-Derived T Cells Improves Their Use in Cancer Immunotherapy. Cell Stem Cell (2018) 23(6):850-8.e4. doi: 10.1016/j.stem.2018.10.005

58. Watarai H, Rybouchkin A, Hongo N, Nagata Y, Sakata S, Sekine E, et al. Generation of Functional NKT Cells In Vitro From Embryonic Stem Cells Bearing Rearranged Invariant V $\alpha 14-J \alpha 18$ Tcro Gene. Blood (2010) 115 (2):230-7. doi: 10.1182/blood-2009-04-217729

59. Ueda N, Uemura Y, Zhang R, Kitayama S, Iriguchi S, Kawai Y, et al. Generation of TCR-Expressing Innate Lymphoid-Like Helper Cells That Induce Cytotoxic T Cell-Mediated Anti-Leukemic Cell Response. Stem Cell Rep (2018) 10(6):1935-46. doi: 10.1016/j.stemcr.2018.04.025

60. Yamada D, Iyoda T, Vizcardo R, Shimizu K, Sato Y, Endo TA, et al. Efficient Regeneration of Human Vo24+ Invariant Natural Killer T Cells and Their Anti-Tumor Activity In Vivo. Stem Cells (2016) 34(12):2852-60. doi: $10.1002 /$ stem. 2465

61. Kitayama S, Zhang R, Liu T-Y, Ueda N, Iriguchi S, Yasui Y, et al. Cellular Adjuvant Properties, Direct Cytotoxicity of Re-Differentiated Vo24 Invariant NKT-Like Cells From Human Induced Pluripotent Stem Cells. Stem Cell Rep (2016) 6(2):213-27. doi: 10.1016/j.stemcr.2016.01.005

62. Sallusto F, Geginat J, Lanzavecchia A. Central Memory and Effector Memory T Cell Subsets: Function, Generation, and Maintenance. Annu Rev Immunol (2004) 22:745-63. doi: 10.1146/annurev.immunol.22.012703.104702

63. Hahn WC, Counter CM, Lundberg AS, Beijersbergen RL, Brooks MW, Weinberg RA. Creation of Human Tumour Cells With Defined Genetic Elements. Nature (1999) 400(6743):464-8. doi: 10.1038/22780
64. Honda T, Ando M, Ando J, Ishii M, Sakiyama Y, Ohara K, et al. Sustainable Tumor-Suppressive Effect of iPSC-Derived Rejuvenated T Cells Targeting Cervical Cancers. Mol Ther (2020) 28(11):2394-405. doi: 10.1016/ j.ymthe.2020.07.004

65. Cahan P, Daley GQ. Origins and Implications of Pluripotent Stem Cell Variability and Heterogeneity. Nat Rev Mol Cell Biol (2013) 14(6):357-68. doi: $10.1038 / \mathrm{nrm} 3584$

66. Nagano S, Maeda T, Ichise H, Kashima S, Ohtaka M, Nakanishi M, et al. High Frequency Production of T Cell-Derived iPSC Clones Capable of Generating Potent Cytotoxic T Cells. Mol Ther Methods Clin Dev (2020) 16:126-35. doi: 10.1016/j.omtm.2019.12.006

67. Suchin EJ, Langmuir PB, Palmer E, Sayegh MH, Wells AD, Turka LA. Quantifying the Frequency of Alloreactive T Cells In Vivo: New Answers to an Old Question. J Immunol (Baltimore Md 1950) (2001) 166(2):973-81. doi: 10.4049/jimmunol.166.2.973

68. Macedo C, Orkis EA, Popescu I, Elinoff BD, Zeevi A, Shapiro R, et al. Contribution of Naïve and Memory T-Cell Populations to the Human Alloimmune Response. Am J Transplant Off J Am Soc Transplant Am Soc Transplant Surgeons (2009) 9(9):2057-66. doi: 10.1111/j.1600-6143.2009. 02742.x

69. Besseyrias V, Fiorini E, Strobl LJ, Zimber-Strobl U, Dumortier A, Koch U, et al. Hierarchy of Notch-Delta Interactions Promoting T Cell Lineage Commitment and Maturation. J Exp Med (2007) 204(2):331-43. doi: $10.1084 /$ jem.20061442

70. Ditadi A, Sturgeon CM. Directed Differentiation of Definitive Hemogenic Endothelium and Hematopoietic Progenitors From Human Pluripotent Stem Cells. Methods (San Diego Calif) (2016) 101:65-72. doi: 10.1016/ j.ymeth.2015.10.001

71. Canu G, Athanasiadis E, Grandy RA, Garcia-Bernardo J, Strzelecka PM, Vallier L, et al. Analysis of Endothelial-to-Haematopoietic Transition at the Single Cell Level Identifies Cell Cycle Regulation as a Driver of Differentiation. Genome Biol (2020) 21(1):157. doi: 10.1186/s13059-02002058-4

72. Kennedy M, Awong G, Sturgeon CM, Ditadi A, LaMotte-Mohs R, ZunigaPflucker JC, et al. T Lymphocyte Potential Marks the Emergence of Definitive Hematopoietic Progenitors in Human Pluripotent Stem Cell Differentiation Cultures. Cell Rep (2012) 2(6):1722-35. doi: 10.1016/ j.celrep.2012.11.003

73. Sturgeon CM, Ditadi A, Awong G, Kennedy M, Keller G. Wnt Signaling Controls the Specification of Definitive and Primitive Hematopoiesis From Human Pluripotent Stem Cells. Nat Biotechnol (2014) 32(6):554-61. doi: $10.1038 /$ nbt.2915

74. Chang C-W, Lai Y-S, Lamb LSJr., Townes TM. Broad T-Cell Receptor Repertoire in T-Lymphocytes Derived From Human Induced Pluripotent Stem Cells. PloS One (2014) 9(5):e97335. doi: 10.1371/journal.pone.0097335

75. Iriguchi S, Yasui Y, Kawai Y, Arima S, Kunitomo M, Sato T, et al. A Clinically Applicable and Scalable Method to Regenerate T-Cells From iPSCs for Off-the-Shelf T-Cell Immunotherapy. Nat Commun (2021) 12 (1):430. doi: 10.1038/s41467-020-20658-3

76. Maeda T, Nagano S, Kashima S, Terada K, Agata Y, Ichise H, et al. Regeneration of Tumor-Antigen-Specific Cytotoxic T Lymphocytes From iPSCs Transduced With Exogenous TCR Genes. Mol Ther Methods Clin Dev (2020) 19:250-60. doi: 10.1016/j.omtm.2020.09.011

77. Kashima S, Maeda T, Masuda K, Nagano S, Inoue T, Takeda M, et al. Cytotoxic T Lymphocytes Regenerated From iPS Cells Have Therapeutic Efficacy in a Patient-Derived Xenograft Solid Tumor Model. iScience (2020) 23(4):100998. doi: 10.1016/j.isci.2020.100998

78. Kumar A, Lee JH, Suknuntha K, D'Souza SS, Thakur AS, Slukvin II. NOTCH Activation at the Hematovascular Mesoderm Stage Facilitates Efficient Generation of T Cells With High Proliferation Potential From Human Pluripotent Stem Cells. J Immunol (Baltimore Md 1950) (2019) 202(3):7706. doi: 10.4049/jimmunol.1801027

79. Montel-Hagen A, Seet CS, Li S, Chick B, Zhu Y, Chang P, et al. OrganoidInduced Differentiation of Conventional T Cells From Human Pluripotent Stem Cells. Cell Stem Cell (2019) 24(3):376-89.e8. doi: 10.1016/ j.stem.2018.12.011

80. Netsrithong R, Suwanpitak S, Boonkaew B, Trakarnsanga K, Chang L-J, Tipgomut C, et al. Multilineage Differentiation Potential of Hematoendothelial 
Progenitors Derived From Human Induced Pluripotent Stem Cells. Stem Cell Res Ther (2020) 11(1):481-. doi: 10.1186/s13287-020-01997-w

81. Kawai Y, Kawana-Tachikawa A, Kitayama S, Ueda T, Miki S, Watanabe A, et al. Generation of Highly Proliferative Rejuvenated Cytotoxic T Cell Clones Through Pluripotency Reprogramming for Adoptive Immunotherapy. Mol Ther J Am Soc Gene Ther (2021) 21:S1525-0016(21)00268-9. doi: 10.1016/ j.ymthe.2021.05.016

82. Ando M, Nishimura T, Yamazaki S, Yamaguchi T, Kawana-Tachikawa A, Hayama T, et al. A Safeguard System for Induced Pluripotent Stem CellDerived Rejuvenated T Cell Therapy. Stem Cell Rep (2015) 5(4):597-608. doi: 10.1016/j.stemcr.2015.07.011

83. Miki A, Jun A, Satoshi Y, Midori I, Yumi S, Sakiko H, et al. Long-Term Eradication of Extranodal Natural Killer/T-Cell Lymphoma, Nasal Type, by Induced Pluripotent Stem Cell-Derived Epstein-Barr Virus-Specific Rejuvenated T Cells In Vivo. Haematologica (2020) 105(3):796-807. doi: 10.3324/haematol.2019.223511

84. Ito T, Kawai Y, Yasui Y, Iriguchi S, Minagawa A, Ishii T, et al. The Therapeutic Potential of Multiclonal Tumoricidal T Cells Derived From Tumor Infiltrating Lymphocyte-Derived iPS Cells. Commun Biol (2021) 4 (1):694. doi: 10.1038/s42003-021-02195-x

85. Kodama H, Nose M, Niida S, Nishikawa S, Nishikawa S. Involvement of the C-Kit Receptor in the Adhesion of Hematopoietic Stem Cells to Stromal Cells. Exp Hematol (1994) 22(10):979-84.

86. Nakano T, Kodama H, Honjo T. Generation of Lymphohematopoietic Cells From Embryonic Stem Cells in Culture. Science (1994) 265(5175):1098-101. doi: $10.1126 /$ science. 8066449

87. Schmitt TM, Zuniga-Pflucker JC. Induction of T Cell Development From Hematopoietic Progenitor Cells by Delta-Like-1 In Vitro. Immunity (2002) 17(6):749-56. doi: 10.1016/S1074-7613(02)00474-0

88. La Motte-Mohs RN, Herer E, Zúñiga-Pflücker JC. Induction of T-Cell Development From Human Cord Blood Hematopoietic Stem Cells by DeltaLike 1 In Vitro. Blood (2005) 105(4):1431-9. doi: 10.1182/blood-2004-04-1293

89. Calvo J, BenYoucef A, Baijer J, Rouyez M-C, Pflumio F. Assessment of Human Multi-Potent Hematopoietic Stem/Progenitor Cell Potential Using a Single In Vitro Screening System. PloS One (2012) 7(11):e50495. doi: 10.1371/journal.pone.0050495

90. Karanu FN, Murdoch B, Miyabayashi T, Ohno M, Koremoto M, Gallacher L, et al. Human Homologues of Delta-1 and Delta-4 Function as Mitogenic Regulators of Primitive Human Hematopoietic Cells. Blood J Am Soc Hematol (2001) 97(7):1960-7. doi: 10.1182/blood.v97.7.1960

91. Hozumi K, Negishi N, Suzuki D, Abe N, Sotomaru Y, Tamaoki N, et al. Delta-Like 1 Is Necessary for the Generation of Marginal Zone B Cells But Not T Cells In Vivo. Nat Immunol (2004) 5(6):638-44. doi: 10.1038/ni1075

92. Mohtashami M, Shah DK, Nakase H, Kianizad K, Petrie HT, ZúñigaPflücker JC. Direct Comparison of Dll1- and Dll4-Mediated Notch Activation Levels Shows Differential Lymphomyeloid Lineage Commitment Outcomes. J Immunol (2010) 185(2):867. doi: 10.4049/ jimmunol.1000782

93. Andrawes MB, Xu X, Liu H, Ficarro SB, Marto JA, Aster JC, et al. Intrinsic Selectivity of Notch 1 for Delta-Like 4 Over Delta-Like 1. J Biol Chem (2013) 288(35):25477-89. doi: 10.1074/jbc.M113.454850

94. Lei F, Haque R, Weiler L, Vrana KE, Song J. T Lineage Differentiation From Induced Pluripotent Stem Cells. Cell Immunol (2009) 260(1):1-5. doi: 10.1016/j.cellimm.2009.09.005

95. Suwanpitak S, Promnakhon N, Netsrithong R, Wattanapanitch M. Efficient Generation of iPSC-Derived Hematoendothelial Progenitors and Specification Toward T Cell Lineage. Methods Mol Biol (Clifton NJ) (2021). doi: 10.1007/7651_2021_355

96. Timmermans F, Velghe I, Vanwalleghem L, De Smedt M, Van Coppernolle S, Taghon T, et al. Generation of T Cells From Human Embryonic Stem Cell-Derived Hematopoietic Zones. J Immunol (Baltimore Md 1950) (2009) 182(11):6879-88. doi: 10.4049/jimmunol.0803670

97. Nishimura T, Nakauchi H. Generation of Antigen-Specific T Cells From Human Induced Pluripotent Stem Cells. Methods Mol Biol (Clifton NJ) (2019) 1899:25-40. doi: 10.1007/978-1-4939-8938-6_3

98. Saito H, Okita K, Chang AE, Ito F. Adoptive Transfer of CD8+ T Cells Generated From Induced Pluripotent Stem Cells Triggers Regressions of
Large Tumors Along With Immunological Memory. Cancer Res (2016) 76 (12):3473-83. doi: 10.1158/0008-5472.can-15-1742

99. Chung B, Montel-Hagen A, Ge S, Blumberg G, Kim K, Klein S, et al. Engineering the Human Thymic Microenvironment to Support Thymopoiesis In Vivo. Stem Cells (2014) 32(9):2386-96. doi: 10.1002/stem.1731

100. Seet CS, He C, Bethune MT, Li S, Chick B, Gschweng EH, et al. Generation of Mature T Cells From Human Hematopoietic Stem and Progenitor Cells in Artificial Thymic Organoids. Nat Methods (2017) 14(5):521-30. doi: 10.1038/nmeth.4237

101. Yano H, Shinohara T, Koga K, Iriguchi S, Miyake Y, Song X, et al. Guided Polarization of iPSC-Derived CD4SP Helper T Cells By CRISPR/Cas9-Based Genome-Editing. Blood (2019) 134(Supplement_1):1937-. doi: 10.1182/ blood-2019-122193

102. Mohtashami M, Shah DK, Kianizad K, Awong G, Zuniga-Pflucker JC. Induction of T-Cell Development by Delta-Like 4-Expressing Fibroblasts. Int Immunol (2013) 25(10):601-11. doi: 10.1093/intimm/dxt027

103. Lapenna A, B-Lynch C, Kapeni C, Aspinall R. A Simple Model System Enabling Human CD34(+) Cells to Undertake Differentiation Towards T Cells. PloS One (2013) 8(7):e69572-e. doi: 10.1371/journal.pone.0069572

104. Varnum-Finney B, Brashem-Stein C, Bernstein ID. Combined Effects of Notch Signaling and Cytokines Induce a Multiple Log Increase in Precursors With Lymphoid and Myeloid Reconstituting Ability. Blood (2003) 101 (5):1784-9. doi: 10.1182/blood-2002-06-1862

105. Ikawa T, Hirose S, Masuda K, Kakugawa K, Satoh R, Shibano-Satoh A, et al. An Essential Developmental Checkpoint for Production of the T Cell Lineage. Science (2010) 329(5987):93-6. doi: 10.1126/science.1188995

106. Taqvi S, Dixit L, Roy K. Biomaterial-Based Notch Signaling for the Differentiation of Hematopoietic Stem Cells Into T Cells. J Biomed Mater Res Part A (2006) 79(3):689-97. doi: 10.1002/jbm.a.30916

107. Shukla S, Langley MA, Singh J, Edgar JM, Mohtashami M, Zuniga-Pflucker JC, et al. Progenitor T-Cell Differentiation From Hematopoietic Stem Cells Using Delta-Like-4 and VCAM-1. Nat Methods (2017) 14(5):531-8. doi: 10.1038/nmeth. 4258

108. Kimbrel EA, Lanza R. Next-Generation Stem Cells - Ushering in a New Era of Cell-Based Therapies. Nat Rev Drug Discovery (2020) 19(7):463-79. doi: 10.1038/s41573-020-0064-x

109. Feucht J, Sun J, Eyquem J, Ho Y-J, Zhao Z, Leibold J, et al. Calibration of CAR Activation Potential Directs Alternative T Cell Fates and Therapeutic Potency. Nat Med (2019) 25(1):82-8. doi: 10.1038/s41591-018-0290-5

110. van der Stegen S, Lindenbergh P, Petrovic R, Whitlock B, Clarke R, Valamehr B, et al. NOTCH and CAR Signaling Control T Cell Lineage Commitment From Pluripotent Stem Cells. Blood (2020) 136(Supplement 1):30doi: 10.1182/blood-2020-142894

111. Mandal M, Clarke R, van der Stegen S, Chang C-W, Lai Y-S, Witty A, et al. Abstract 3245: FT819 Path to IND: First-Of-Kind Off-the-Shelf CAR19 TCell for B Cell Malignancies. Cancer Res (2020) 80(16 Supplement):3245. doi: 10.1158/1538-7445.AM2020-3245

112. Chang C, van der Stegen S, Mili M, Clarke R, Lai Y-S, Witty A, et al. FT819: Translation of Off-The-Shelf TCR-Less Trac-1xx CAR-T Cells in Support of First-Of-Kind Phase I Clinical Trial. Blood (2019) 134(Supplement_1):4434-. doi: 10.1182/blood-2019-130584

113. Clarke R, van der Stegen S, Chang C-W, Husain M, Lai Y-S, Peralta E, et al. Pluripotent Cell-Derived Off-The-Shelf TCR-Less CAR-Targeted Cytotoxic $\mathrm{T}$ Cell Therapeutic for the Allogeneic Treatment of B Cell Malignancies. Blood (2018) 132(Supplement 1):4546-. doi: 10.1182/blood-2018-99-116843

114. Park JH, Jain N, Chen A, McGuirk JP, Diaz M, Valamehr B, et al. A Phase I Study of FT819, a First-Of-Kind, Off-The-Shelf, iPSC-Derived TCR-Less CD19 CAR T Cell Therapy for the Treatment of Relapsed/Refractory B-Cell Malignancies. Blood (2020) 136(Supplement 1):15-6. doi: 10.1182/blood2020-142423

115. Deuse T, Hu X, Gravina A, Wang D, Tediashvili G, De C, et al. Hypoimmunogenic Derivatives of Induced Pluripotent Stem Cells Evade Immune Rejection in Fully Immunocompetent Allogeneic Recipients. Nat Biotechnol (2019) 37(3):252-8. doi: 10.1038/s41587-019-0016-3

116. Gornalusse GG, Hirata RK, Funk SE, Riolobos L, Lopes VS, Manske G, et al. HLA-E-Expressing Pluripotent Stem Cells Escape Allogeneic Responses and Lysis by NK Cells. Nat Biotechnol (2017) 35(8):765-72. doi: 10.1038/nbt.3860 
117. Xu H, Wang B, Ono M, Kagita A, Fujii K, Sasakawa N, et al. Targeted Disruption of HLA Genes via CRISPR-Cas9 Generates iPSCs With Enhanced Immune Compatibility. Cell Stem Cell (2019) 24(4):566-78.e7. doi: 10.1016/ j.stem.2019.02.005

118. Shi L, Li W, Liu Y, Chen Z, Hui Y, Hao P, et al. Generation of Hypoimmunogenic Human Pluripotent Stem Cells via Expression of Membrane-Bound and Secreted $32 \mathrm{~m}-\mathrm{HLA}-\mathrm{G}$ Fusion Proteins. Stem Cells (2020) 38(11):1423-37. doi: 10.1002/stem.3269

119. Wang B, Iriguchi S, Waseda M, Ueda N, Ueda T, Xu H, et al. Generation of Hypoimmunogenic T Cells From Genetically Engineered Allogeneic Human Induced Pluripotent Stem Cells. Nat Biomed Eng (2021) 5(5):429-40. doi: 10.1038/s41551-021-00730-z

120. Thongsin N, Wattanapanitch M. CRISPR/Cas9 Ribonucleoprotein ComplexMediated Efficient B2M Knockout in Human Induced Pluripotent Stem Cells (iPSCs). Methods Mol Biol (Clifton NJ) (2021). doi: 10.1007/7651_2021_352

121. Han X, Wang M, Duan S, Franco PJ, Kenty JH, Hedrick P, et al. Generation of Hypoimmunogenic Human Pluripotent Stem Cells. Proc Natl Acad Sci USA (2019) 116(21):10441-6. doi: 10.1073/pnas.1902566116

122. Malik NN, Jenkins AM, Mellon J, Bailey G. Engineering Strategies for Generating Hypoimmunogenic Cells With High Clinical and Commercial Value. Regener Med (2019) 14(11):983-9. doi: 10.2217/rme-2019-0117

123. Koga K, Wang B, Kaneko S. Current Status and Future Perspectives of HLAEdited Induced Pluripotent Stem Cells. Inflammation Regener (2020) 40:23. doi: 10.1186/s41232-020-00132-9

124. Lanza R, Russell DW, Nagy A. Engineering Universal Cells That Evade Immune Detection. Nat Rev Immunol (2019) 19(12):723-33. doi: 10.1038/ s41577-019-0200-1

125. Sugita S, Makabe K, Iwasaki Y, Fujii S, Takahashi M. Natural Killer Cell Inhibition by HLA-E Molecules on Induced Pluripotent Stem Cell-Derived Retinal Pigment Epithelial Cells. Invest Ophthalmol Vis Sci (2018) 59 (5):1719-31. doi: 10.1167/iovs.17-22703

126. Fauriat C, Andersson S, Björklund AT, Carlsten M, Schaffer M, Björkström NK, et al. Estimation of the Size of the Alloreactive NK Cell Repertoire: Studies in Individuals Homozygous for the Group A KIR Haplotype. J Immunol (Baltimore Md 1950) (2008) 181(9):6010-9. doi: 10.4049/ jimmunol.181.9.6010

127. Chang C, Peralta E, Hsia G, Yang B-H, Yeh W-I, Clarke R, et al. Generation of Multiplexed Engineered, Off-The-Shelf CAR T Cells Uniformly Carrying Multiple Anti-Tumor Modalities to Prevent Tumor Relapse. Blood (2020) 136(Supplement 1):11-. doi: 10.1182/blood-2020-138930

128. Crowther MD, Dolton G, Legut M, Caillaud ME, Lloyd A, Attaf M, et al. Genome-Wide CRISPR-Cas9 Screening Reveals Ubiquitous T Cell Cancer Targeting via the Monomorphic MHC Class I-Related Protein MR1. Nat Immunol (2020) 21(2):178-85. doi: 10.1038/s41590-019-0578-8

129. Nguyen C, Peralta E, Chang C-W, Yeh W-I, Pan Y, Lu D, et al. Multiplexed Engineered, Off-The-Shelf $\mathrm{T}$ Cells Carrying Three Tumor-Associated Antigen-Targeting Modalities: CAR + Pan-Tumor Targeting TCR + CD16 Fc Receptor. Blood (2020) 136(Supplement 1):32-. doi: 10.1182/blood-2020141507

130. Ando M, Nakauchi H. 'Off-the-Shelf' Immunotherapy With iPSC-Derived Rejuvenated Cytotoxic T Lymphocytes. Exp Hematol (2017) 47:2-12. doi: $10.1016 / \mathrm{j}$.exphem.2016.10.009

131. Morgan MA, Büning H, Sauer M, Schambach A. Use of Cell and Genome Modification Technologies to Generate Improved "Off-The-Shelf" CAR T and CAR NK Cells. Front Immunol (2020) 11:1965(1965). doi: 10.3389/ fimmu. 2020.01965

132. Nianias A, Themeli M. Induced Pluripotent Stem Cell (iPSC)-Derived Lymphocytes for Adoptive Cell Immunotherapy: Recent Advances and Challenges. Curr Hematol Malig Rep (2019) 14(4):261-8. doi: 10.1007/ s11899-019-00528-6

133. Doi D, Magotani H, Kikuchi T, Ikeda M, Hiramatsu S, Yoshida K, et al. PreClinical Study of Induced Pluripotent Stem Cell-Derived Dopaminergic Progenitor Cells for Parkinson's Disease. Nat Commun (2020) 11(1):3369. doi: $10.1038 / \mathrm{s} 41467-020-17165-\mathrm{w}$
134. Umekage M, Sato Y, Takasu N. Overview: An iPS Cell Stock at CiRA. Inflammation Regener (2019) 39:17-. doi: 10.1186/s41232-019-0106-0

135. Wattanapanitch M. Recent Updates on Induced Pluripotent Stem Cells in Hematological Disorders. Stem Cells Int (2019) 2019:5171032. doi: 10.1155/ 2019/5171032

136. Dzilic E, Lahm H, Dreßen M, Deutsch M-A, Lange R, Wu SM, et al. Genome Editing Redefines Precision Medicine in the Cardiovascular Field. Stem Cells Int (2018) 2018:4136473-. doi: 10.1155/2018/4136473

137. Montel-Hagen A, Crooks GM. From Pluripotent Stem Cells to T Cells. Exp Hematol (2019) 71:24-31. doi: 10.1016/j.exphem.2018.12.001

138. Guo R, Wu H, Du J, Wang J. T Cell Regeneration: An Update on Progress and Challenges. Blood Sci (2020) 2(1):22-6. doi: 10.1097/BS9.0000 000000000037

139. Takahashi J. iPS Cell-Based Therapy for Parkinson's Disease: A Kyoto Trial. Regenerative Ther (2020) 13:18-22. doi: 10.1016/j.reth.2020.06.002

140. Ando M, Nishimura T, Yamazaki S, Yamaguchi T, Kawana-Tachikawa A, Hayama T, et al. A Safeguard System for Induced Pluripotent Stem CellDerived Rejuvenated T Cell Therapy. Stem Cell Rep (2015) 5(4):597-608. doi: 10.1016/j.stemcr.2015.07.011

141. Sadelain M, Rivière I, Riddell S. Therapeutic T Cell Engineering. Nature (2017) 545(7655):423-31. doi: 10.1038/nature22395

142. Zhou JT, Liu JH, Song TT, Ma B, Amidula N, Bai C. EGLIF-CAR-T Cells Secreting PD-1 Blocking Antibodies Significantly Mediate the Elimination of Gastric Cancer. Cancer Manag Res (2020) 12:8893-902. doi: 10.2147/ cmar.S260915

143. Ping Y, Li F, Nan S, Zhang D, Shi X, Shan J, et al. Augmenting the Effectiveness of CAR-T Cells by Enhanced Self-Delivery of PD-1-Neutralizing scFv. Front Cell Dev Biol (2020) 8:803. doi: 10.3389/fcell.2020.00803

144. Pegram HJ, Purdon TJ, van Leeuwen DG, Curran KJ, Giralt SA, Barker JN, et al. IL-12-Secreting CD19-Targeted Cord Blood-Derived T Cells for the Immunotherapy of B-Cell Acute Lymphoblastic Leukemia. Leukemia (2015) 29(2):415-22. doi: 10.1038/leu.2014.215

145. Chmielewski M, Abken H. CAR T Cells Releasing IL-18 Convert to T-Bet (high) FoxO1(low) Effectors That Exhibit Augmented Activity Against Advanced Solid Tumors. Cell Rep (2017) 21(11):3205-19. doi: 10.1016/ j.celrep.2017.11.063

146. Chen Y, Sun C, Landoni E, Metelitsa L, Dotti G, Savoldo B. Eradication of Neuroblastoma by T Cells Redirected With an Optimized GD2-Specific Chimeric Antigen Receptor and Interleukin-15. Clin Cancer Res (2019) 25 (9):2915-24. doi: 10.1158/1078-0432.Ccr-18-1811

147. Hawkins ER, D'Souza RR, Klampatsa A. Armored CAR T-Cells: The Next Chapter in T-Cell Cancer Immunotherapy. Biologics (2021) 15:95-105. doi: $10.2147 /$ btt.S291768

148. Zhang L, Tian L, Dai X, Yu H, Wang J, Lei A, et al. Pluripotent Stem CellDerived CAR-Macrophage Cells With Antigen-Dependent Anti-Cancer Cell Functions. J Hematol Oncol (2020) 13(1):153. doi: 10.1186/s13045-02000983-2

Conflict of Interest: The authors declare that the research was conducted in the absence of any commercial or financial relationships that could be construed as a potential conflict of interest.

Publisher's Note: All claims expressed in this article are solely those of the authors and do not necessarily represent those of their affiliated organizations, or those of the publisher, the editors and the reviewers. Any product that may be evaluated in this article, or claim that may be made by its manufacturer, is not guaranteed or endorsed by the publisher.

Copyright $\odot 2021$ Netsrithong and Wattanapanitch. This is an open-access article distributed under the terms of the Creative Commons Attribution License (CC BY). The use, distribution or reproduction in other forums is permitted, provided the original author(s) and the copyright owner(s) are credited and that the original publication in this journal is cited, in accordance with accepted academic practice. No use, distribution or reproduction is permitted which does not comply with these terms. 